\title{
Ship- and island-based soundings from the 2016 EI Niño Rapid Response (ENRR) field campaign
}

\author{
Leslie M. Hartten ${ }^{1,2}$, Christopher J. Cox ${ }^{1,2}$, Paul E. Johnston ${ }^{1,2}$, Daniel E. Wolfe ${ }^{1,2}$, Scott Abbott ${ }^{2}$, \\ H. Alex McColl ${ }^{1,2, a}$, Xiao-Wei Quan ${ }^{1,2}$, and Matthew G. Winterkorn ${ }^{3,4}$ \\ ${ }^{1}$ Cooperative Institute for Research in Environmental Science (CIRES), University of Colorado, \\ Boulder, 80309-0216, USA \\ ${ }^{2}$ NOAA/Earth System Research Laboratory, Physical Sciences Division, Boulder, 80305, USA \\ ${ }^{3}$ NVision Solutions, Diamondhead, Mississippi, 39525, USA \\ ${ }^{4}$ NOAA National Data Buoy Center, Stennis Space Center, Mississippi, 39529, USA \\ ${ }^{\mathrm{a}}$ current address: Berthoud, Colorado, 80513, USA \\ Correspondence: Leslie M. Hartten (leslie.m.hartten@noaa.gov)
}

Received: 22 January 2018 - Discussion started: 14 February 2018

Revised: 9 May 2018 - Accepted: 11 May 2018 - Published: 20 June 2018

\begin{abstract}
As the 2015/2016 El Niño was gathering strength in late 2015, scientists at the Earth System Research Laboratory's Physical Sciences Division proposed and led the implementation of the National Oceanic and Atmospheric Administration's (NOAA's) El Niño Rapid Response (ENRR) Field Campaign. ENRR observations included wind and thermodynamic profiles of the atmosphere over the near-equatorial eastern central Pacific Ocean, many of which were collected from two field sites and transmitted in near-real time for inclusion in global forecasting models. From 26 January to 28 March 2016, twice-daily rawinsonde observations were made from Kiritimati (pronounced "Christmas") Island (2.0 $\mathrm{N}, 157.4^{\circ} \mathrm{E}$; call sign CXENRR). From 16 February to 16 March 2016, three to eight radiosondes were launched each day from NOAA Ship Ronald H. Brown (allocated call sign WTEC) as it travelled southeast from Hawaii to service Tropical Atmosphere Ocean (TAO) buoys along longitudes 140 and $125^{\circ} \mathrm{W}$ and then north to San Diego, California. Both the rapid and remote nature of these deployments created particular difficulties in collecting and disseminating the soundings; these are described together with the methods used to reprocess the data after the field campaign finished. The reprocessed and lightly quality-controlled data have been put into an easy-to-read text format, qualifying them to be termed "Level 2" soundings. They are archived and freely available for public access at NOAA's National Centers for Environmental Information (NCEI) in the form of two separate data sets: one consisting of 125 soundings from Kiritimati (https://doi.org/10.7289/V55Q4T5K), the other of 193 soundings from NOAA Ship Ronald H. Brown (https://doi.org/10.7289/V5X63K15). Of the Kiritimati soundings, $94 \%$ reached the tropopause and $88 \%$ reached $40 \mathrm{hPa}$, while $89 \%$ of the ship's soundings reached the tropopause and $87 \%$ reached $40 \mathrm{hPa}$. The soundings captured the repeated advance and retreat of the Intertropical Convergence Zone (ITCZ) at Kiritimati, a variety of marine tropospheric environments encountered by the ship, and lower-stratospheric features of the 2015-2016 QBO (quasi-biennial oscillation), all providing a rich view of the local atmosphere's response to the eastern central Pacific's extremely warm waters during the 2015/16 El Niño.
\end{abstract}




\section{Introduction}

In early 2015, signs of a long-anticipated El Niño event began to appear in the Pacific Ocean. Both dynamical and statistical models were forecasting the continuation and likely strengthening of El Niño conditions in June 2015 (Climate Prediction Center (CPC) and International Research Institute for Climate and Society (IRI), 2015a). By August 2015, CPC and IRI (2015b) were describing the event as "significant" with high confidence that a strong event would peak in the late fall or early winter. The National Oceanic and Atmospheric Administration (NOAA), aware of the potential for large impacts on weather in the United States, wanted to respond quickly to the emerging forecasting challenges. Thus, the El Niño Rapid Response (ENRR) program was instituted as a joint effort by both operational and research-oriented sectors within the NOAA. Coordinated, targeted fieldwork was proposed as one element of ENRR by the Earth System Research Laboratory's (ESRL) Physical Sciences Division (PSD; Dole et al., 2018). The resulting ENRR Field Campaign, led by PSD but involving many partners within and outside of the NOAA, had several observational and research components, including hundreds of atmospheric profiles of temperature, humidity and winds measured by radiosondes launched from Kiritimati (pronounced "Christmas") Island and NOAA Ship Ronald H. Brown. This paper documents the collection of these soundings, their reprocessing with improved surface data, the initial quality control applied, and the resulting data sets.

\section{Field sites and data collection}

\subsection{Kiritimati, Republic of Kiribati}

The Line Islands lie south of Hawaii, extending from $6.4^{\circ} \mathrm{N}$ to $11.4^{\circ} \mathrm{S}$ (Fig. 1). Kiritimati ${ }^{1}$, whose highest point is $13 \mathrm{~m}$ a.s.l. and whose land area is $321 \mathrm{~km}^{2}$, is the largest of these islands (Scott, 1993). About 6500 residents live in four villages on the northern and western portions of the island (Morate, 2016), while the southern portion is now designated as a bird sanctuary. Physical contact with the outside world is limited; during most of 2016 there were two international passenger flights each week, occurring during one round trip between Fiji and Hawaii which stops at Kiritimati in both directions. Most supplies are imported on monthly freight flights from Hawaii and during irregular visits by freighter ships. There is Internet access on the island but it is slow, perhaps $0.26 \mathrm{Mbps}$ downloading and $0.03 \mathrm{Mbps}$ uploading on a good day. Some of the best Internet connectivity on the island is at the Captain Cook Hotel.

The Captain Cook Hotel, located in the Main Camp neighborhood of Banana village, was the center of our ENRR oper-

\footnotetext{
${ }^{1}$ In the Gilbertese (Kiribati) language, "ti" respresents an "ss" sound. Hence, Kiribati is pronounced "KEER-eh-bahss", and Kiritimati is the Gilbertese spelling of "Christmas".
}

ations. The hotel property is located on the northeast-facing coast (Fig. 2) and has hosted NOAA scientists in the past. The grounds are sandy and moderately vegetated, predominantly with short grasses and similar plants but also with some shrubs and coconut palms. The short beach runs steeply down to shallow water that extends for tens of meters to the edge of the reef; beyond that, the reef drops off sharply and the water is hundreds of meters deep. For 9 weeks PSD maintained a staff of two observers who occupied both sides of a two-unit bungalow. One of the bungalow's units also housed the computers and radiosonde equipment. Helium tanks were stored in the southern corner of the large $(13 \mathrm{~m}$ by $31 \mathrm{~m})$ concrete pad outside the bungalow. The concrete pad was very slightly higher than the ground on which our bungalow and the surface station sat, but overall the area where observations were collected was flat and fairly level.

Site setup began on 25 January 2016. A tripod was positioned north of the bungalow and east of the concrete pad, and outfitted with an R. M. Young 5103 anemometer, a tipping bucket rain gauge, a shielded Vaisala HMP45C temperature and relative humidity probe, and a box containing a Vaisala PT101B barometer and a Campbell Scientific CR23X datalogger. Above the box was a solar panel which charged the battery that provided power to the datalogger. This tripod was moved northeast about $10 \mathrm{~m}$, to a location just above the beach, on 5 February 2016. More details of the surface instrumentation, as well as an explanation of the post-deployment processing of the collected surface observations, are found in Hartten et al. (2018).

The first Vaisala RS92-SGP radiosonde was launched at 11:36 UTC on 26 January 2016. Typically, one observer was primarily responsible for filling the balloon. A flattened tarpaulin tube, held together by a strong Velcro pull-strip running its entire length, was laid on the somewhat sheltered concrete porch outside the bungalow and the $350 \mathrm{~g}$ balloon was laid inside it. The balloon was connected to an analog regulator attached to one of the gas cans and the balloon was filled with approximately 600 PSI of helium, or until the balloon was about the same length as the tube. (We were unable to use lift weights to determine when the balloons were filled because we lacked anything resembling an inflation shed to keep the filling balloon protected from the wind and weather during the process.) The other observer was generally inside the bungalow, using the Vaisala GC25 ground-check set (Vaisala Oyj, 2006) and the DigiCORA sounding software (Vaisala Oyj, 2010b; version 3.64.1) to calibrate and initialize the radiosonde and set the sounding parameters. The DigiCORA software was directed to run in "research mode" so that it would continue to collect data during the downward trajectory of the radiosonde after the balloon burst. After the ground check was complete and the battery pack was connected, the radiosonde was usually carried outside and set on the surface station's instrument box, in the shade of the station's solar panel. This provided a well-ventilated location for the radiosonde to equilibrate to outdoor conditions and 


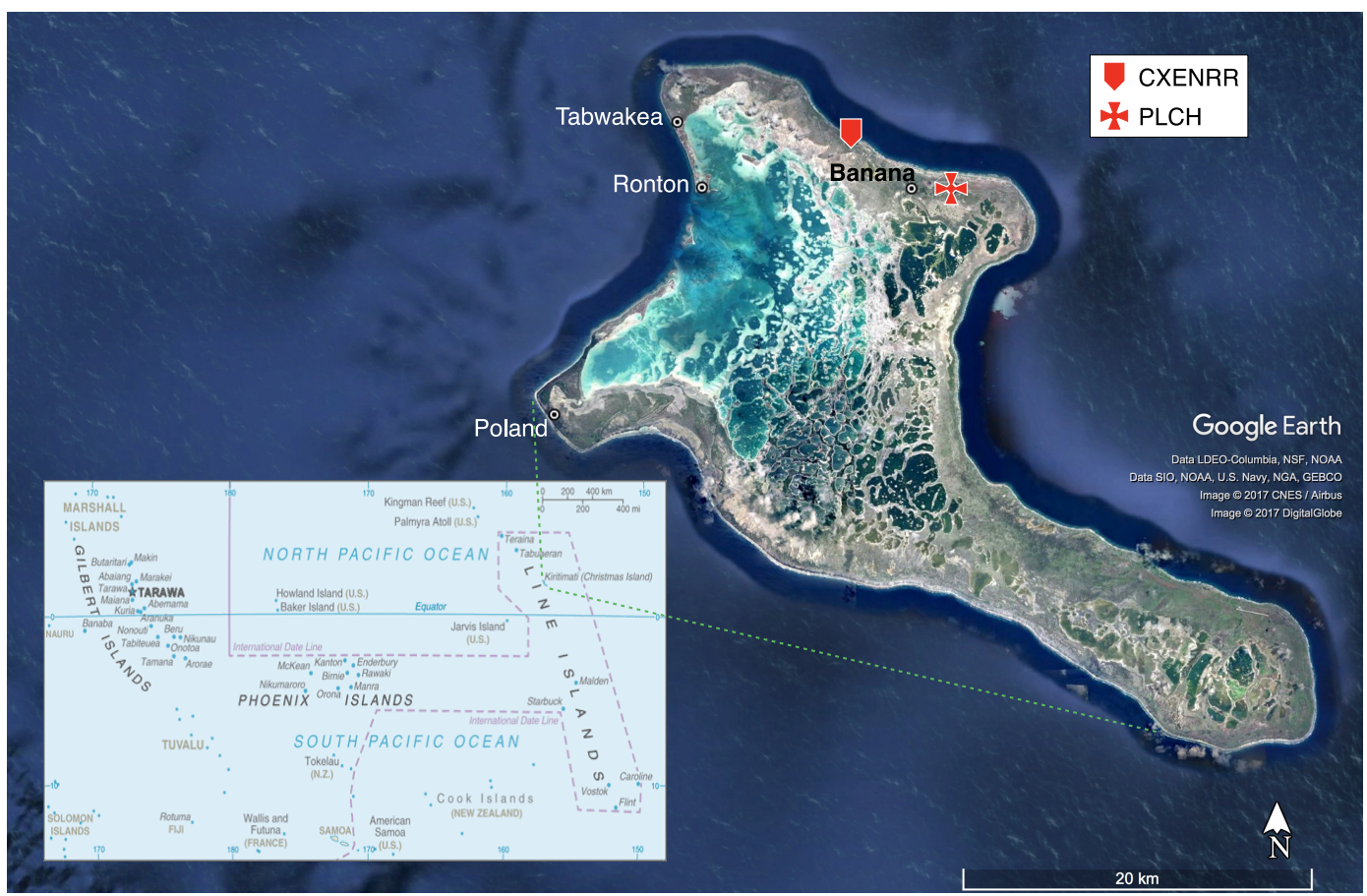

Figure 1. Composite satellite photo of Kiritimati showing the location of the four population centers, Cassidy International Airport (International Civil Aviation Organization (ICAO) airport code PLCH), and the ENRR field site (CXENRR). The inset map shows Kiritimati's location within the Line Islands and the Republic of Kiribati in general. Kiribati map by the U.S. Central Intelligence Agency courtesy of the University of Texas Libraries, The University of Texas at Austin. Station symbol colors from www.ColorBrewer.org by Cynthia A. Brewer, Geography, Pennsylvania State University.

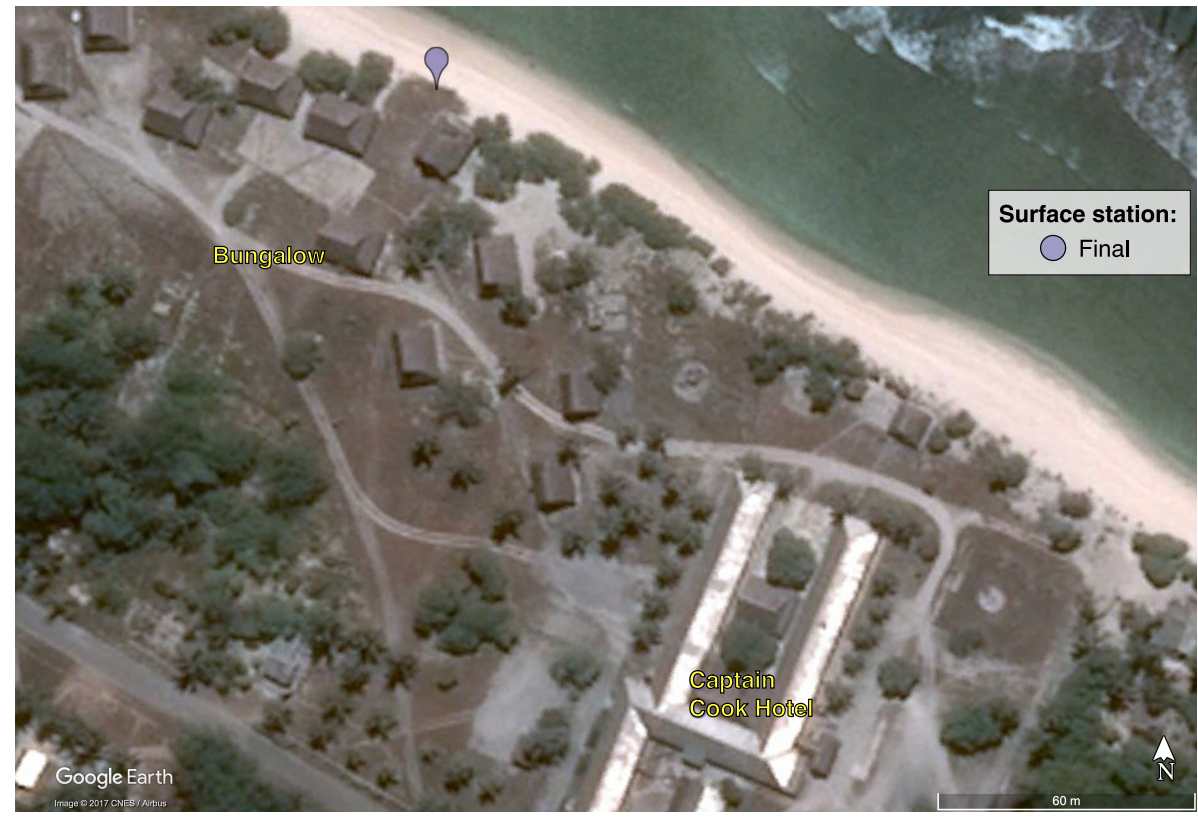

Figure 2. Aerial view of the Captain Cook Hotel property on Kiritimati, including the CXENRR site (upper left). The final location of the surface meteorology instruments is at the base of the pin symbol, north-northeast of the bungalow that housed staff and the Vaisala DigiCORA sounding system. The concrete pad where the helium tanks were stored and from which balloons were launched runs northwest to southeast, ending just north of the bungalow. The main hotel building used for Internet access is southeast of the CXENRR site. 
acquire GPS lock. It also allowed for several minutes of independent pressure, temperature and humidity measurements co-located with the surface meteorological station. When it was time to launch, surface observations from the meteorological station were entered into the DigiCORA software; the radiosonde was attached to the balloon and then released from the concrete pad or the grassy space south of it and west of the bungalow. The coordinates $\left(2.01^{\circ} \mathrm{N}, 157.40^{\circ} \mathrm{W}\right)$ adequately describe the location of both the surface station and the area from which the radiosonde was launched.

Our goal was to collect 00:00 and 12:00 UTC soundings, so in accordance with WMO guidelines (World Meteorological Organization, 2013; see Part III Sect. 2.4.10) launches typically occurred $30-45 \mathrm{~min}$ before the nominal sounding time (i.e., 23:15-23:30 and 11:15-11:30 UTC). We monitored the launch from inside the bungalow, and relaunched if the radiosonde did not reach $400 \mathrm{hPa}$ (Office of the Federal Coordinator for Meteorology (OFCM), 2006). This only happened once, with the 7 February 2016, 12:00 UTC sounding. The system had occasional trouble locking on to enough GPS satellites to get position readings, but typically only for short segments of a flight. There were also signal dropouts when the radiosonde was in the null directly over the site's telemetry antenna. After the balloon burst, we continued to monitor the radiosonde until we ceased receiving data. When the data collection finished, we used the DigiCORA software's simulation feature to run the radiosonde transmissions through the software's "non-research" (operational) mode and created TEMP, PILOT, and BUFR messages from the operationalmode sounding data. After we ran a script to apply the proper WMO wrappers to the TEMP messages, the WMO, PILOT, BUFR, and research-mode text files were then compressed into a single file for transmission to Boulder, Colorado, via the Internet access point at the main hotel building. Compression into one file was necessary because the Internet was slow and tended to drop the connection after each transfer; even so, we were not always able to get the file to Boulder in the desired time window. Computer scripts in Boulder uncompressed the file and pushed the TEMP message to the NOAA's National Center for Environmental Prediction (NCEP) Central Operations for transmission to the Global Telecommunication System (GTS).

While "CXI" is a common abbreviation for Kiritimati and is the International Air Transport Association (IATA) airport code for the local airport, we chose to use "CXENRR" as the station name to clearly distinguish these data from a variety of past meteorological data collections. The ICAO code assigned to Kiritimati is "PLCH", which is used for METAR and other data collected by the Kiribati Weather Service on Kiritimati.

There were two exceptions to the standard launch times. We did an extra launch on 2 March 2016 at 20:17 UTC. This involved coordinated transmissions with several amateur radio antennas that were to operate at $3.505-28.010 \mathrm{MHz}$ near our bungalow for 2 weeks, in order to verify that

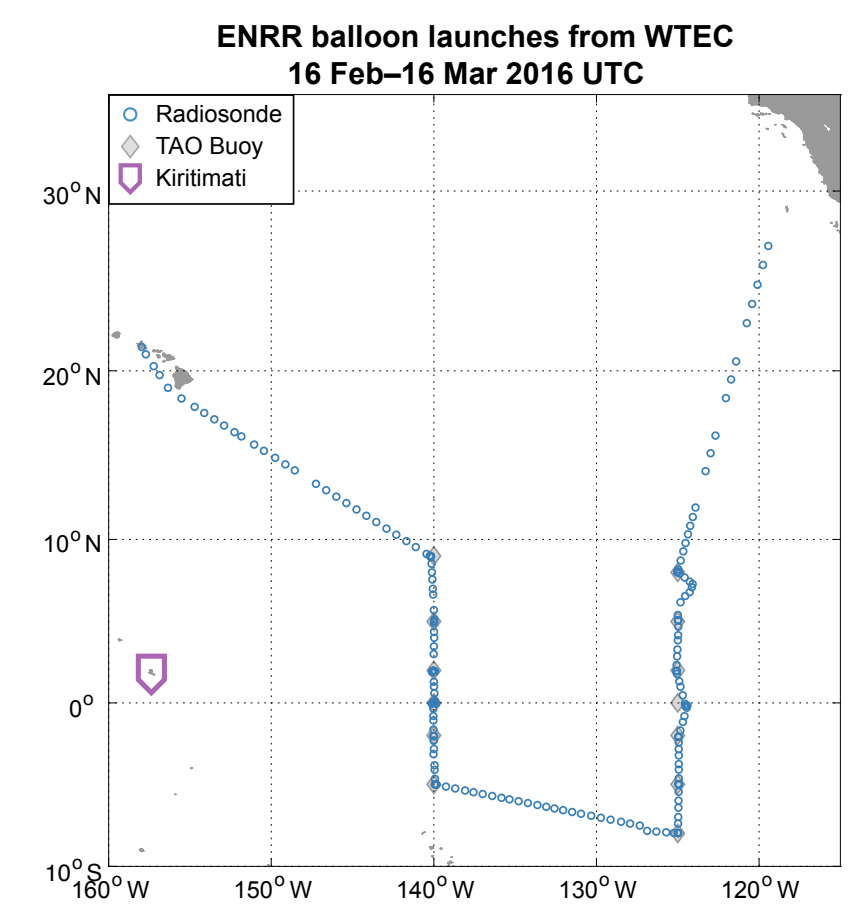

Figure 3. The release locations of all rawinsonde observations collected by NOAA Ship Ronald H. Brown during ENRR, 16 February-16 March 2017. Colors from www.ColorBrewer.org by Cynthia A. Brewer, Geography, Pennsylvania State University.

there was no interference with our sounding data collection. The 00:00 UTC sounding on 10 March 2016 was not launched until 03:24 UTC (yielding a nominal sounding time of 03:00 UTC) because of a power failure at the hotel. Over the course of our deployment, we successfully collected 125 soundings.

\subsection{NOAA Ship Ronald H. Brown}

NOAA Ship Ronald H. Brown, part of the NOAA's Marine Operations Center - Atlantic (MOC-A) fleet, is a Global Class research vessel that has been in service since 1997. It was scheduled to perform routine servicing of the Tropical Atmosphere Ocean (TAO) array buoys along 140 and $125^{\circ} \mathrm{W}$ in February and March 2016. These buoys' position within the area of warm SST anomalies associated with the ongoing El Niño motivated a collaborative effort in which the ENRR Field Campaign was able to deploy three scientists and radiosonde equipment on the ship during the cruise. The objective of the ship-based ENRR sounding campaign was to collect atmospheric profiles of temperature, humidity and winds six times per day (at 00:00, 04:00, 08:00, 12:00, 16:00, and 20:00 UTC) at the beginning of the campaign, while the ship travelled from Hawaii southeast to the first scheduled TAO buoy position at $\left(9^{\circ} \mathrm{N}, 140^{\circ} \mathrm{W}\right)$; eight times per day (at 00:00, 03:00, 06:00, 09:00, 12:00, 15:00, 18:00, and 21:00 UTC) while the ship was near the anomalously warm 
Table 1. Coordinated soundings during the ENRR Field Campaign. Radiosondes were launched from either the ship or the island, and dropsondes were released from the NOAA Gulfstream-IV (G-IV). The horizontal distance between launch points was calculated using Great Circle navigational formulae by the NOAA/National Hurricane Center calculator at http://www.nhc.noaa.gov/gccalc.shtml.

\begin{tabular}{|c|c|c|c|c|c|c|c|}
\hline \multicolumn{3}{|c|}{ Radiosonde } & \multicolumn{3}{|c|}{ Dropsonde } & \multirow[b]{2}{*}{ Time between } & \multirow[b]{2}{*}{ Distance between } \\
\hline Nominal time & Release time & Release location & Release location & Release time & Flight & & \\
\hline \multicolumn{8}{|c|}{ NOAA Ship Ronald H. Brown } \\
\hline $\begin{array}{l}\text { 17 February 2016, } \\
\text { 20:00 UTC }\end{array}$ & $\begin{array}{l}17 \text { February } 2016, \\
21: 32 \text { UTC }\end{array}$ & $18.39^{\circ} \mathrm{N}, 155.52^{\circ} \mathrm{W}$ & $18.22^{\circ} \mathrm{N}, 155.72^{\circ} \mathrm{W}$ & $\begin{array}{l}\text { 17 February 2016, } \\
21: 26 \text { UTC }\end{array}$ & RF12 & 00:06 & $28 \mathrm{~km}$ \\
\hline $\begin{array}{l}18 \text { February } 2016 \text {, } \\
\text { 22:00 UTC }\end{array}$ & $\begin{array}{l}18 \text { February } 2016 \text {, } \\
22: 01 \text { UTC }\end{array}$ & $16.42^{\circ} \mathrm{N}, 152.26^{\circ} \mathrm{W}$ & $16.21^{\circ} \mathrm{N}, 151.80^{\circ} \mathrm{W}$ & $\begin{array}{l}18 \text { February } 2016 \text {, } \\
21: 53 \text { UTC }\end{array}$ & RF13 & 00:08 & $54 \mathrm{~km}$ \\
\hline $\begin{array}{l}22 \text { February } 2016 \text {, } \\
\text { 00:00 UTC }\end{array}$ & $\begin{array}{l}\text { 21 February 2016, } \\
23: 46 \text { UTC }\end{array}$ & $9.12^{\circ} \mathrm{N}, 140.45^{\circ} \mathrm{W}$ & $9.00^{\circ} \mathrm{N}, 140.01^{\circ} \mathrm{W}$ & $\begin{array}{l}21 \text { February 2016, } \\
23: 51 \text { UTC }\end{array}$ & RF14 & 00:05 & $50 \mathrm{~km}$ \\
\hline \multicolumn{8}{|l|}{ Kiritimati } \\
\hline $\begin{array}{l}27 \text { February } 2016 \text {, } \\
\text { 00:00 UTC }\end{array}$ & $\begin{array}{l}26 \text { February } 2016, \\
23: 19 \text { UTC }\end{array}$ & $2.01^{\circ} \mathrm{N}, 157.40^{\circ} \mathrm{W}$ & $1.99^{\circ} \mathrm{N}, 157.04^{\circ} \mathrm{W}$ & $\begin{array}{l}26 \text { February } 2016 \text {, } \\
23: 26 \text { UTC }\end{array}$ & RF15 & 00:07 & $40 \mathrm{~km}$ \\
\hline
\end{tabular}

water between $8^{\circ} \mathrm{N}$ and $8^{\circ} \mathrm{S}$ conducting the TAO maintenance (from 140 to $125^{\circ} \mathrm{W}$ ); and six times per day again during the final leg north to San Diego from $\left(8^{\circ} \mathrm{N}, 125^{\circ} \mathrm{W}\right)$. With a few exceptions, we carried out this schedule, collecting 193 profiles from 16 February to 16 March (Fig. 3). This total includes 135 soundings between $8^{\circ} \mathrm{N}$ and $8^{\circ} \mathrm{S}$, as well as three launches in mid-February that were coordinated with dropsondes deployed nearby by the NOAA Gulfstream-IV (G-IV; see Table 1). The G-IV conducted numerous research flights over the tropical Pacific as part of the ENRR Field Campaign (Dole et al., 2018). During these three launches the shipboard ENRR staff were in close contact with scientists from the G-IV mission and adjusted their launch times as best they could in order to get nearly coincident launches from ship and plane.

\subsubsection{General launch procedures}

Launch preparation took place in two adjoining locations on the main deck: in the staging bay just forward of the fantail, and in an air-conditioned lab to port of that bay (Fig. 4). One observer ran the Vaisala RS92-SGP radiosondes through the standard Vaisala ground-check and initialization procedure in the small lab. After this, the radiosonde was placed outside in a safe place on the fantail to equilibrate to ambient conditions until just prior to launch. The radiosonde was always put on something that was elevated approximately $1 \mathrm{~m}$ above the fantail's deck, and in a location that was as shaded as possible. The equilibration time was several minutes and the radiosonde was determined to be equilibrated when the real-time data feed showed that both the temperature and humidity had stabilized to outside conditions.

While one observer prepared the radiosonde, another was in the staging bay filling the $350 \mathrm{~g}$ latex balloon ${ }^{2}$ with helium.

\footnotetext{
${ }^{2}$ The first sounding, launched on 16 February 2016 at 19:02 UTC from Pearl Harbor, Hawaii, used a $200 \mathrm{~g}$ balloon in order to conserve supplies because it was primarily a demonstration launch. The soundings launched on 28 February 2016 at 20:10 UTC
}

The staging bay's roll-down doors face aft, have a $5.5 \mathrm{~m}$ vertical clearance, and were open, as was a narrower tall doorway on the starboard side of the staging bay. The bay thus provided incomplete shelter from the wind, with the resulting localized turbulence preventing a direct and consistent measure of lift using weights. Instead, the amount of helium required to achieve the optimum $5 \mathrm{~m} \mathrm{~s}^{-1}$ ascent rate was determined by trial and error based on ascent rate and helium use during previous launches, and in consultation with the ENRR observers on Kiritimati. Finally, the equilibrated radiosonde was brought to the staging bay and attached to the filled balloon; surface observations were entered into the DigiCORA software; there was a final check that the radiosonde's temperature, relative humidity, and pressure were working and that the GPS receiver was in contact with at least four GPS satellites; and then the pair was brought out onto the fantail for launch.

The fantail of the ship typically experiences a substantial amount of turbulence caused by high winds (gusting to 15$20 \mathrm{~m} \mathrm{~s}^{-1}$ free stream) passing through the ship's superstructure. Since the main purpose of this cruise was to exchange TAO buoys in order to restore data, the fantail area was also generally crowded with recovered and not-yet-deployed buoys. Both factors made launches challenging. During the day, the balloon launches had to be coordinated with deck operations on the fantail involving the buoy maintenance. In several cases, this coordination resulted in late launches. At night, the ship was typically underway, which often increased the relative wind speed and local turbulence compared to daytime conditions. Ten to fifteen minutes prior to every launch the bridge was notified of our intent. If the ship was underway, we first checked the relative wind speed and direction to determine whether we would ask the bridge to adjust the ship's course and speed to optimize a fantail launch. (Due

and 2 March 2016 at 02:10 UTC also employed $200 \mathrm{~g}$ balloons as part of experimentation designed to improve our launch success rate. 


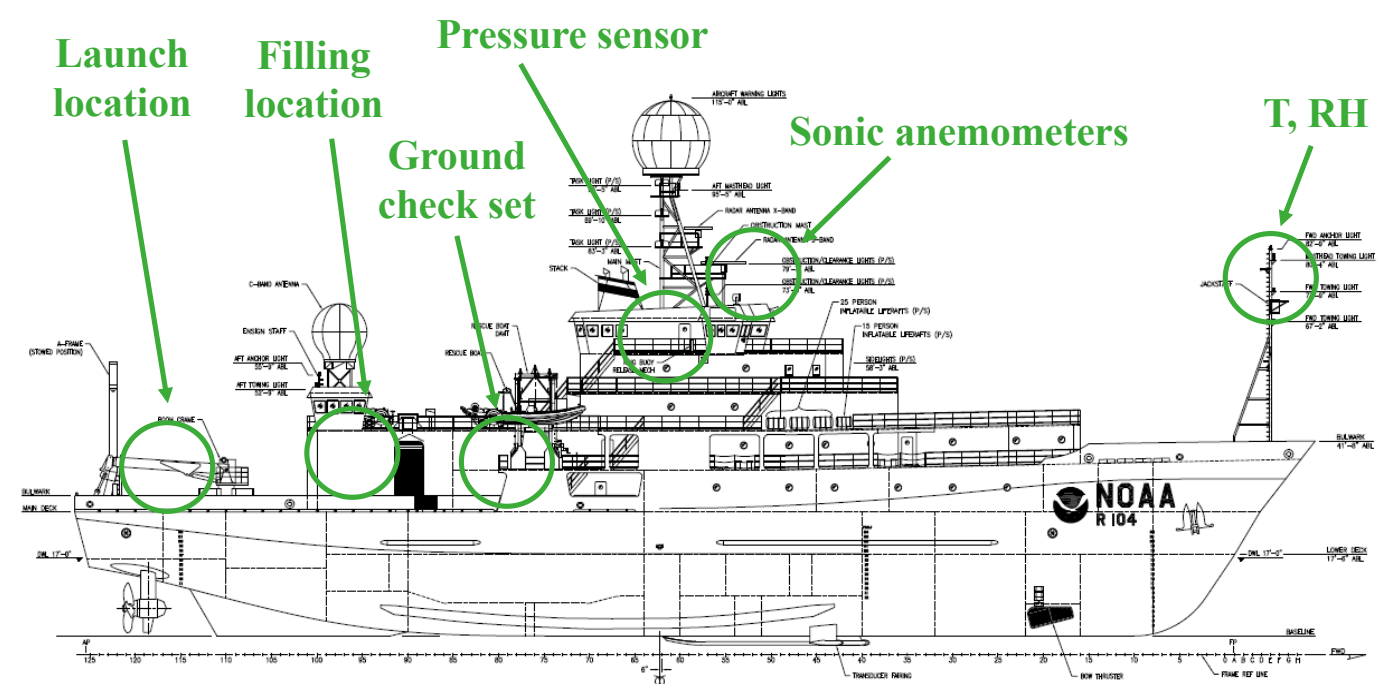

Figure 4. Schematic of NOAA Ship Ronald H. Brown annotated to show the location of key surface meteorological instruments as well as the staging bay where the balloons were filled and the approximate location of the fantail, where they were launched. Annotation colors from www.ColorBrewer.org by Cynthia A. Brewer, Geography, Pennsylvania State University.

to the ship's tight schedule, slowing the ship was not always possible.) The actual launch was from whatever position on the fantail that the operators estimated would maximize the likelihood of success.

As at Kiritimati, the DigiCORA software was run in "research mode" and continued to collect data after the balloon burst, stopping only when transmission ceased because of splashdown or loss of signal. The sounding was then simulated in "non-research" (operational) mode. BUFR and TEMP messages were created from the operational mode data using the ship's assigned call sign, "WTEC", and appropriate WMO headers were applied to the TEMP messages. Then both the "research mode" and "non-research mode" sets of text sounding files as well as the BUFR and TEMP messages were uploaded to Boulder, from whence the TEMP messages were pushed to NOAA/NCEP's Central Operations for transmission to the GTS.

Conditions on the fantail resulted in a number of failed launches, for example when swirling winds drove the radiosonde into the superstructure or the ocean. In some cases, we successfully attempted a second launch; in other cases, the sounding was skipped. We had limited supplies of radiosondes, balloons, and helium, so many factors were taken into account in the decision to relaunch: the likelihood of a repeat failure, whether there was sufficient time remaining to collect and send the data before the next launch, and how critical data from this time period were. Of the 206 planned soundings, 13 scheduled launch times $(6 \%)$ were missed due to failures of the initial launch.

The above descriptions of launch conditions and procedures are likely applicable to RS92 radiosonde launches from NOAA Ship Ronald H. Brown during cruises associ- ated with various multi-year programs. These would include AEROSE (Aerosols and Ocean Science Expeditions, Nalli et al., 2011), AMMA (African Monsoon Multidisciplinary Analysis, Lebel et al., 2010), PIRATA (originally Pilot Research Moored Array in the Tropical Atlantic (Servain et al., 1998), now Prediction and Research Moored Array in the Tropical Atlantic, Bourlès et al., 2008), and the Stratus Project (part of the Eastern Pacific Investigation of Climate (EPIC) program; see de Szoeke et al., 2010, and references therein). Exceptions would tend to be related to the cruisespecific arrangement of objects on the fantail, and the resulting effects on where radiosondes could be placed while equilibrating and from where they could be launched.

\subsubsection{Special conditions and atypical soundings}

Solar heating of the fantail deck often increased the air temperature where the radiosonde was equilibrated before daytime launches. We have compared the temperature from the corrected surface meteorology data set (Cox et al., 2017b) to that recorded by the radiosondes on the fantail deck after equilibration but prior to launch. The surface meteorology was collected independently by the ship's standard complement of instruments; instrument details and post-processing are documented in Hartten et al. (2018). The differences between fantail conditions as measured by the radiosondes during their equilibration time and the contemporaneous post-processed surface data were $+0.59^{\circ} \mathrm{C} \pm 0.6^{\circ} \mathrm{C}$ during the day (i.e., when solar zenith angle was less than $90^{\circ}$ ) compared to $+0.04{ }^{\circ} \mathrm{C} \pm 0.2^{\circ} \mathrm{C}$ when the sun was below the horizon. There is a corresponding difference in relative humidity $(-3.61 \% \pm 3.74 \%$ during the day compared to $-0.01 \% \pm 1.43 \%$ at night). We have made no attempt to 
Table 2. ENRR soundings from NOAA Ship Ronald H. Brown which contain no winds due to GPS issues.

\begin{tabular}{|c|c|c|}
\hline Nominal time & Release time & Release location \\
\hline & TC & \\
\hline & 3 February $2016,20: 10$ UTC & $5.13^{\circ} \mathrm{N}$, \\
\hline :00 UTC & Iary $2016,23: 16$ UTC & $5.03^{\circ} \mathrm{N}$, \\
\hline 25 February 2016, 02:00 UTC & 2016, 02:13 UTC & $1.98^{\circ} \mathrm{N}$ \\
\hline $\mathrm{TC}$ & JTC & $1.98^{\circ} \mathrm{N}$ \\
\hline 25 February 2016, 08:00 UTC & 25 February 2016, 08:20 UTC & $1.89^{\circ} \mathrm{N}, 140.11^{\circ} \mathrm{W}$ \\
\hline & & $1.94^{\circ} \mathrm{N}$ \\
\hline 25 February 2016 & JTC & $1.97^{\circ} \mathrm{N}$ \\
\hline $25 \mathrm{~F}$ & $25 \mathrm{~F}$ & $1.96^{\circ} \mathrm{N}$ \\
\hline ГС & TC & $1.30^{\circ} \mathrm{N}$ \\
\hline $26 \mathrm{H}$ & 26 & $1.00^{\circ} \mathrm{N}$, \\
\hline & TC & $0.59^{\circ} \mathrm{N}$ \\
\hline 261 & 26 & $0.12^{\circ} \mathrm{N}$ \\
\hline & TC & $0.00^{\circ} \mathrm{N}$ \\
\hline$\Gamma \mathrm{C}$ & TC & $0.02^{\circ} \mathrm{N}$ \\
\hline & & $0.02^{\circ} \mathrm{N}$ \\
\hline & & $0.03^{\circ} \mathrm{N}$ \\
\hline & & \\
\hline 27 February 20 & $27 \mathrm{~F}$ & $0.04^{\circ} \mathrm{N}, 139.97^{\circ} \mathrm{W}$ \\
\hline & & \\
\hline $27 \mathrm{Fe}$ & uary $2016,11: 1$ & $0.05^{\circ} \mathrm{S}, 139.86^{\circ} \mathrm{W}$ \\
\hline $27 \mathrm{Feb}$ & ruary $2016,14: 10 \mathrm{UTC}$ & $0.04^{\circ} \mathrm{N}, 140.06^{\circ} \mathrm{W}$ \\
\hline $27 \mathrm{~F}$ & $27 \mathrm{~F}$ & $0.03^{\circ} \mathrm{N}, 139.97^{\circ} \mathrm{W}$ \\
\hline 27 Febr & 27 February 2016, 20:16 UTC & $0.03^{\circ} \mathrm{N}, 140.03^{\circ} \mathrm{W}$ \\
\hline $29 \mathrm{Feb}$ & tary $2016,11: 21 \mathrm{UTC}$ & $3.83^{\circ} \mathrm{S}, 139.96^{\circ} \mathrm{W}$ \\
\hline 3 March 2016, 17:00 & 3 March 2016, 17:13 UTC & $7.29^{\circ} \mathrm{S}, 128.49^{\circ} \mathrm{W}$ \\
\hline
\end{tabular}

change any sounding data based on this information, but are documenting it here for interested researchers.

During the cruise, the DigiCORA sounding system experienced problems tracking GPS satellites. Even though it had contact at launch with at least the minimum four satellites required to calculate winds, the station would sometimes lose contact with all satellites after launch. After consulting with Vaisala we determined there was failing hardware in the GPS receiver card within the DigiCORA sounding processing subsystem (SPS220; Vaisala Oyj, 2010a, b). As a result, we collected no wind data in 26 of our soundings; 24 of the affected soundings (Table 2) were launched on 2327 February 2016. A variety of other issues affected about $10 \%$ of the launches (Table 3). Ground checks were occasionally skipped during relaunches because of timing issues; if the sonde did not go up immediately, by the time the data were collected and formatted the window for uploading the data would be past. Lack of a ground check could affect the temperature and humidity measurements in the final sounding, but any pressure affects should be mitigated by the reprocessing described in Sect. 3.1. Sometimes visual observation indicated that the spool did not unwind properly or fully after launch. This could lead to unrepresentative measurements caused by the instruments "being too close to the radiation environment of the balloon or ... encountering the balloon's wake as it ascends" (OFCM, 2006), or to erroneous winds because the instruments were swinging on a shorter "pendulum" than expected by the software. On a few occasions the radiosonde passed through the ship's exhaust; this is discussed further in Sect. 3.1. Finally, some balloons were influenced by the flow through the moving ship and its cargo in ways that made the balloon drop perilously close to the water before moving away from the ship and then gaining altitude. We have made no attempt to systematically identify these cases, but users of the data may encounter signs of this in the initial seconds of some soundings.

\section{Sounding correction and quality control}

\subsection{Reprocessing with corrected surface values}

The atmospheric soundings collected by these radiosondes are "anchored" by the independent surface pressure, temperature, humidity, and wind values fed to the DigiCORA system during the launch procedure. These surface data become the first level of the sounding profiles and the DigiCORA software uses them as it begins to process the data transmitted from the radiosonde and create the profile. Therefore, the surface observations influence the profile, generally only quite close to the surface for temperature and humid- 
Table 3. ENRR soundings from NOAA Ship Ronald H. Brown with other known issues.

\begin{tabular}{llr}
\hline Nominal time & Release time & Release location \\
\hline Bad relative humidity sensor(s) & & \\
\hline 17 February 2016, 03:00 UTC & 17 February 2016, 03:28 UTC & $20.95^{\circ} \mathrm{N}, 157.71^{\circ} \mathrm{W}$ \\
24 February 2016, 17:00 UTC & 24 February 2016, 17:11 UTC & $3.00^{\circ} \mathrm{N}, 140.01^{\circ} \mathrm{W}$ \\
29 February 2016, 05:00 UTC & 29 February 2016, 05:09 UTC & $2.83^{\circ} \mathrm{S}, 140.00^{\circ} \mathrm{W}$ \\
13 March 2016, 00:00 UTC & 12 March 2016, 23:09 UTC & $11.93^{\circ} \mathrm{N}, 123.91^{\circ} \mathrm{W}$ \\
14 March 2016, 18:00 UTC & 14 March 2016, 17:12 UTC & $19.50^{\circ} \mathrm{N}, 121.72^{\circ} \mathrm{W}$ \\
\hline No ground check & & \\
\hline 18 February 2016, 22:00 UTC & 18 February 2016, 22:01 UTC & $2.83^{\circ} \mathrm{S}, 140.00^{\circ} \mathrm{W}$ \\
25 February 2016, 20:00 UTC & 25 February 2016, 20:20 UTC & $1.98^{\circ} \mathrm{N}, 140.01^{\circ} \mathrm{W}$ \\
29 February 2016, 00:00 UTC & 28 February 2016, 23:45 UTC & $2.04^{\circ} \mathrm{S}, 140.00^{\circ} \mathrm{W}$ \\
29 February 2016, 12:00 UTC & 29 February 2016, 11:21 UTC & $3.83^{\circ} \mathrm{S}, 139.96^{\circ} \mathrm{W}$ \\
8 March 2016, 17:23 UTC & 8 March 2016, 17:22 UTC & $1.95^{\circ} \mathrm{N}, 125.09^{\circ} \mathrm{W}$ \\
\hline Spool not properly unwound & & \\
\hline 21 February 2016, 19:00 UTC & 21 February 2016, 19:12 UTC & $9.54^{\circ} \mathrm{N}, 141.11^{\circ} \mathrm{W}$ \\
29 February 2016, 08:00 UTC & 29 February 2016, 08:14 UTC & $3.15^{\circ} \mathrm{S}, 140.02^{\circ} \mathrm{W}$ \\
3 March 2016, 02:00 UTC & 3 March 2016, 02:17 UTC & $6.69^{\circ} \mathrm{S}, 131.50^{\circ} \mathrm{W}$ \\
3 March 2016, 20:00 UTC & 3 March 2016, 20:11 UTC & $7.40^{\circ} \mathrm{S}, 127.93^{\circ} \mathrm{W}$ \\
8 March 2016, 02:00 UTC & 8 March 2016, 02:08 UTC & $0.05^{\circ} \mathrm{S}, 124.56^{\circ} \mathrm{W}$ \\
9 March 2016, 05:00 UTC & 9 March 2016, 05:04 UTC & $2.86^{\circ} \mathrm{N}, 125.04^{\circ} \mathrm{W}$ \\
12 March 2016, 02:00 UTC & 12 March 2016, 02:08 UTC & $8.18^{\circ} \mathrm{N}, 124.97^{\circ} \mathrm{W}$ \\
12 March 2016, 05:00 UTC & 12 March 2016, 05:09 UTC & $8.72^{\circ} \mathrm{N}, 124.82^{\circ} \mathrm{W}$ \\
\hline Balloon passed through ship exhaust & \\
\hline 5 March 2016, 05:00 UTC & 5 March 2016, 05:05 UTC & $7.00^{\circ} \mathrm{S}, 124.97^{\circ} \mathrm{W}$ \\
5 March 2016, 12:00 UTC & 5 March 2016, 11:10 UTC & $6.00^{\circ} \mathrm{S}, 124.95^{\circ} \mathrm{W}$ \\
10 March 2016, 12:00 UTC & 10 March 2016, 11:11 UTC & $6.18^{\circ} \mathrm{N}, 124.83^{\circ} \mathrm{W}$ \\
\hline
\end{tabular}

ity and approximately throughout the lower 300-400 $\mathrm{m}$ for the winds. Surface data are also used at one point in the pre-launch process, when surface pressure is entered during the ground check so the Vaisala GC25 can calibrate the radiosonde's barometer.

At both locations there were two types of issues with the surface data that were entered into the DigiCORA software in the field. First, it was obvious during the campaign that at least some surface instruments were incorrectly calibrated or not well positioned. Second, site staff did not have realtime access to averaged data, but had to make their best subjective estimate of representative values to enter, often from on-screen values that were updating at $1 \mathrm{~Hz}$. Therefore, the first step in producing research-quality rawinsonde data sets was to correct the archived surface meteorology at both locations, as described in Hartten et al. (2018). The resulting Kiritimati data (Hartten et al., 2017b) are at 2 min resolution through 11 February 2016, 04:05:43 UTC and at $1 \mathrm{~min}$ resolution thereafter, while the corrected surface data from NOAA Ship Ronald H. Brown (Cox et al., 2017b) are all at 1 min resolution. With the exception of the pressure data, as explained below, we consider these corrected surface mete- orology data appropriate for initializing the research-quality rawinsonde observations.

At CXENRR, the radiosonde ground check occurred within one of the bungalow units, which was typically cooled by an air conditioner set to $20-25^{\circ} \mathrm{C}$. The surface meteorology instrumentation was outside, about $29 \mathrm{~m}$ from the Vaisala GC25 until 5 February 2016, 21:00-22:00 UTC, when it was relocated to a position about $39 \mathrm{~m}$ away. The barometer height at the surface station's final location was $3.6 \mathrm{~m}$ a.s.1. As the campaign progressed the observers realized they were seeing pressure differences between the radiosonde at the ground-check set and the radiosonde when co-located with the surface station. We attempted to quantify this during the post-deployment data processing by comparing the original station-recorded (not corrected) surface pressure with collocated pressure data from 101 radiosondes (Fig. 5). The mean difference was $0.155 \mathrm{hPa}$, with the radiosonde pressure lower than the station pressure in spite of the fact that the radiosonde pressure had been set equal to the station pressure during the ground check. This difference would correspond to a height difference of $1.29 \mathrm{~m}$ between the GC25 and the station barometer, much greater than 


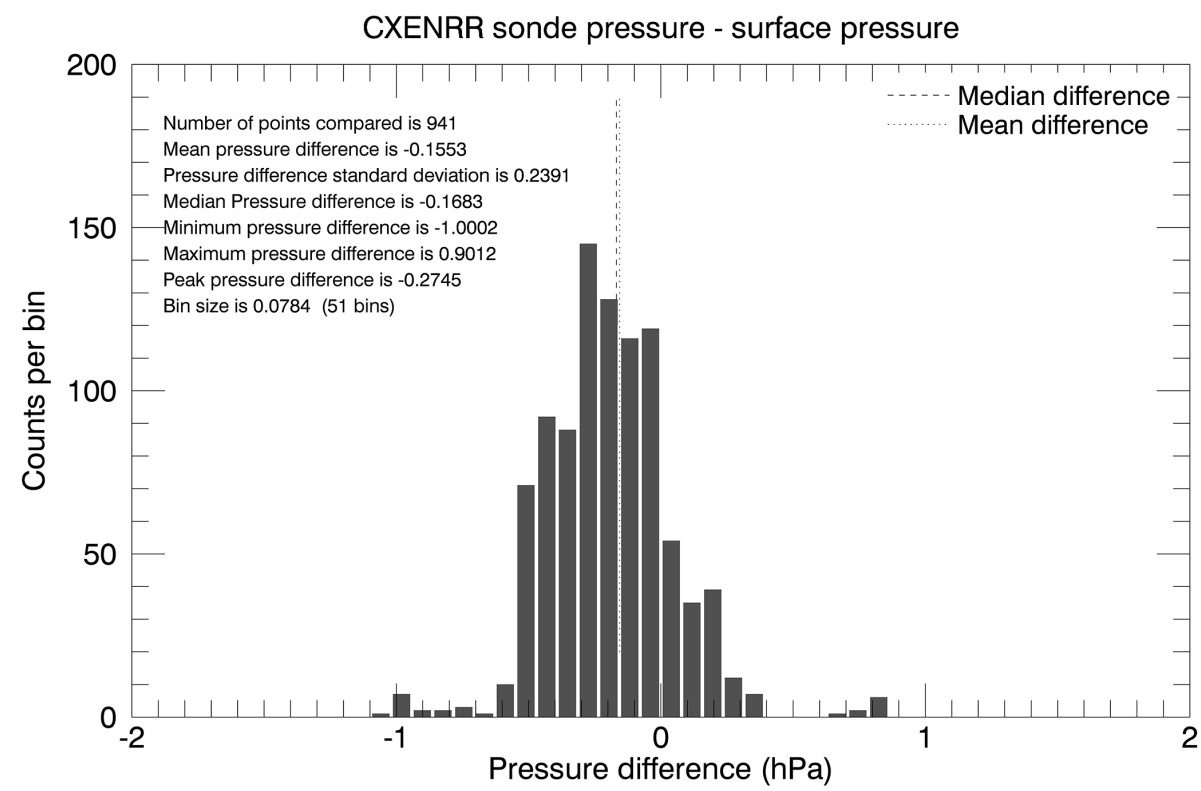

Figure 5. The distribution of the difference between 1 min average Kiritimati radiosonde pressures and 1 min average surface pressures when the radiosonde was co-located with the surface instruments prior to launch. All available data from 101 distinct radiosondes are included.

the measured ${ }^{3}$ difference of 0.03 to $0.09 \mathrm{~m}$. We therefore attribute part of the pressure difference to a height difference between the two locations, but the main part to the pressure from the air-conditioning system that slightly raised the room pressure. As a result, when creating the CXENRR radiosonde data sets documented here, the corrected CXENRR surface pressure described in Hartten et al. (2018) was decreased by $0.155 \mathrm{hPa}$ before being used as a reference pressure during the ground-check phase of reprocessing each sounding.

A similarly subtle issue with surface pressure occurred on the ship. In the field, the pressure entered into the software during the ground check was from the radiosonde itself, while it equilibrated on the fantail. We did this because it was the only available measurement at that moment, but it was inadequate because it was not independent and the radiosonde is re-calibrated during this process. The reprocessing used surface pressure based on measurements from the ship's barometer, a Vaisala PTB330 last calibrated on 29 December 2015 and positioned at $15.24 \mathrm{~m}$ on the port side of the bridge. We first adjusted the pressure reported by the PTB330 to $3.8 \mathrm{~m}$, the height of the radiosonde ground-check set; these became the values in the corrected surface meteorology data set. As documented in Hartten et al. (2018) flow distortion around the superstructure of the ship made pres-

\footnotetext{
${ }^{3}$ On 28 March 2016 the observers used a tape measure, some clothes line, and the horizontal level within a camera that was mounted on a tripod to twice estimate the height difference between the Vaisala GC25 ground-check set and the bottom of the datalogger box on the surface station. The inbound comparison indicated that the GC25 was $0.035 \mathrm{~m}$ below the station, while the outbound comparison indicated it was $0.093 \mathrm{~m}$ above.
}

sures from the PTB330 biased slightly high when the port side of the ship was facing into the wind and slightly low when it was on the lee side. Since the ship passed southbound through the trade winds during the first part of the cruise and northbound back through the trade winds on the return, the bias was generally positive during the first half of the campaign $(0.15 \pm 0.21 \mathrm{hPa})$ and negative during the second half $(-0.17 \pm 0.24 \mathrm{hPa})$. We developed a correction as a function of relative (with respect to the ship's heading) wind direction and applied it to the height-adjusted PTB330 pressures (i.e., to the WTEC corrected surface pressures described in Hartten et al., 2018). We used the resulting time series during the radiosonde reprocessing, both as calibration inputs for the radiosonde ground checks and as surface observations. When there were insufficient data available to make the bias correction, the average bias $(1.1 \mathrm{hPa})$ observed in the radiosonde pressure sensors during the campaign was used to calibrate the radiosonde sensor. For additional details on the handling of ship surface pressures, see Hartten et al. (2018).

After the surface data from both sites were corrected and the surface pressures subjected to the further adjustments described above, all soundings were reprocessed using the simulation feature of Vaisala's DigiCORA sounding software (Vaisala Oyj, 2010a, b; version 3.64.1). The pressure, temperature, humidity, and winds, which would be entered as surface values during a real-time pre-launch process, instead came from the corrected surface meteorology data (plus the additional pressure corrections for CXENRR and for WTEC) at the time closest to launch. For WTEC soundings, initial position information came from the radiosonde, if available, valid at the listed time; otherwise, position information was 


\section{Soundings through the exhaust plume of the NOAA Ship Ronald $\mathrm{H}$. Brown (post-processed with corrected surface meteorology)}
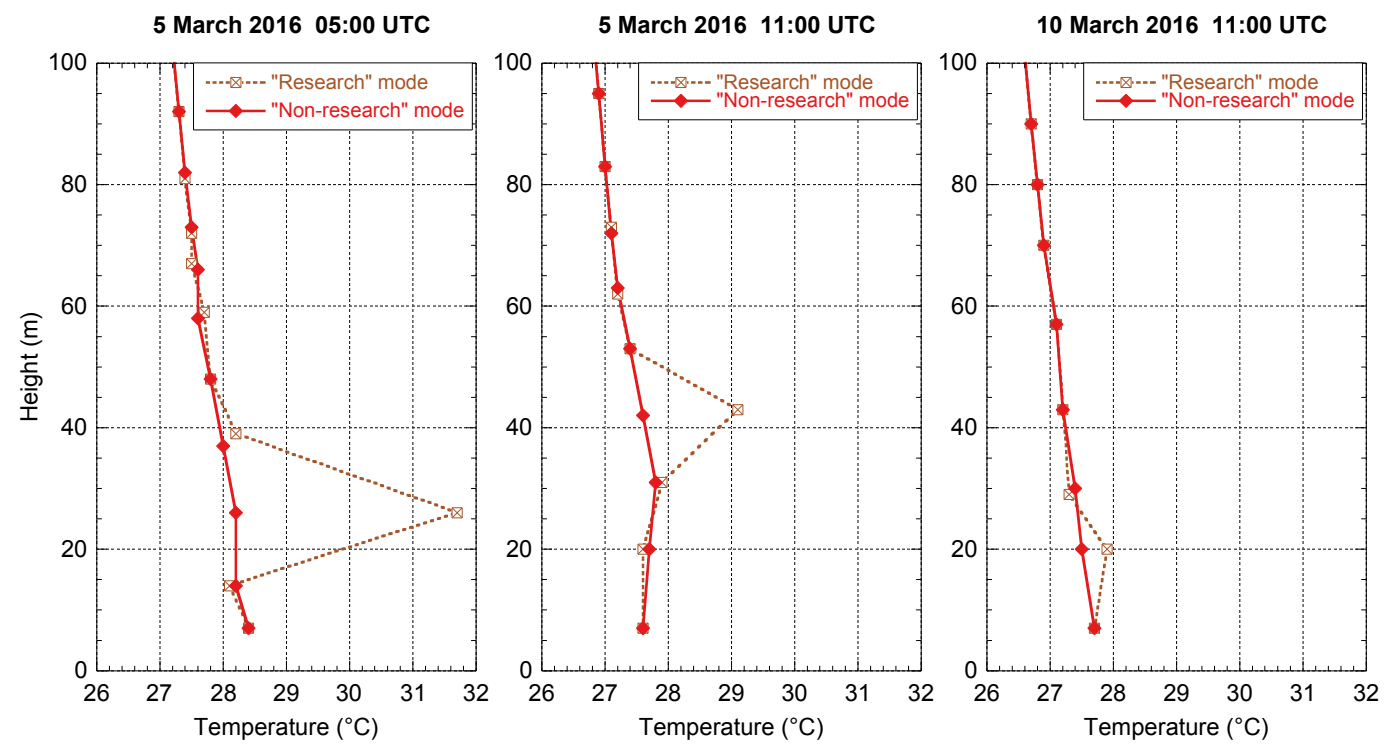

Figure 6. A comparison of "research mode" and "non-research mode" DigiCORA processing on temperature soundings believed to have been collected as the radiosonde passed through the exhaust plume of NOAA Ship Ronald H. Brown. The "non-research mode" soundings were used in the creation of the data sets described in the text. Data colors from www.ColorBrewer.org by Cynthia A. Brewer, Geography, Pennsylvania State University.

from the corrected surface data set. The corrected surface winds for WTEC are based on true (earth-relative) winds. These were measured winds which were adjusted by the onboard Science Computer System (SCS) to account for the ship's speed over ground, course over ground, and heading, but not for pitch, roll, and yaw. We viewed this as a more appropriate choice than ship-relative winds because ENRR's focus was the atmosphere's large-scale response to the strong El Niño and we therefore wanted soundings that were representative of the area in which the radiosondes were launched. Reprocessing was done using the standard "non-research" mode that is employed for operational synoptic soundings, and thus was only applied to the data collected as the balloons ascended (Vaisala Oyj, 2010b). This mode corrects for solar radiation effects as well as for the pendulum motion of the instrument package below the balloon, and also performs some interpolation across small data gaps and some undefined filtering.

The effects of the interpolation and filtering in one particular situation can be seen in Fig. 6. The ship's log book identified three soundings for which it appeared that the radiosonde passed through the ship's exhaust shortly after launch (Table 3); this feature is evident in the raw data, but there is no thermal signature in the final data files. We therefore performed a second simulation of those soundings in the "research" mode, which corrects for solar radiation and pendulum effects but otherwise "is designed to produce data that is edited as little as possible, because it is intended for re- search use only" (Vaisala Oyj, 2010b). Processing through the "research" mode leaves intact a temperature spike in the lowest $100 \mathrm{~m}$ of each sounding, but running the DigiCORA software in "non-research" mode removed the temperature spikes associated with the ship's exhaust.

\subsection{Automated quality control}

After the reprocessing, all soundings were subjected to automated quality control using ASPEN (Atmospheric Sounding Processing ENvironment) software (University Corporation for Atmospheric Research (UCAR), 2016; version 3.3-265), which largely served to remove large random errors in the data. The software was run with the "upsonde-1 s" parameter settings, except for those settings related to GPS or satellites. ASPEN removed data that failed objective QC checks; smoothed the wind, pressure, temperature, and relative humidity; recomputed geopotential height; and computed the radiosonde ascent rate (Martin, 2007). This post-processing satisfies the quality-control aspects of what Ciesielski et al. (2012) define as "Stage 2" or "Level 2" sounding data sets. While an assessment of the quantitative changes and uncertainties associated with the reprocessing described in Sect. 3.1 and the quality control performed by ASPEN could be of interest to some segments of the user community, exploring that issue is beyond the scope of our objective. Such an analysis more naturally proceeds from the development of "Level 3" sounding data, which has been examined and cor- 
(a)

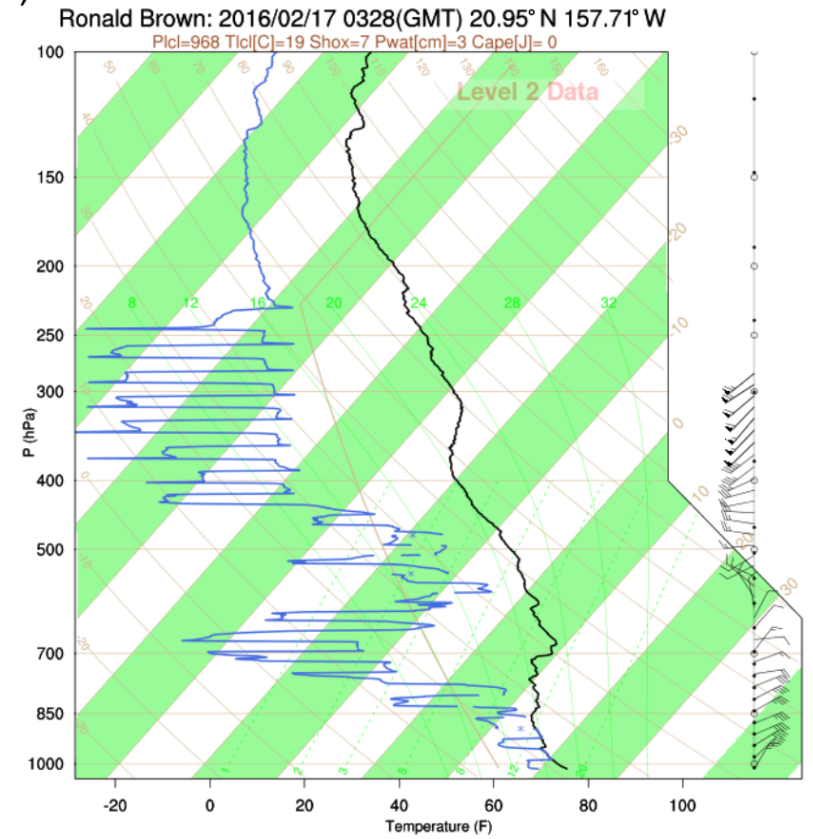

(c)

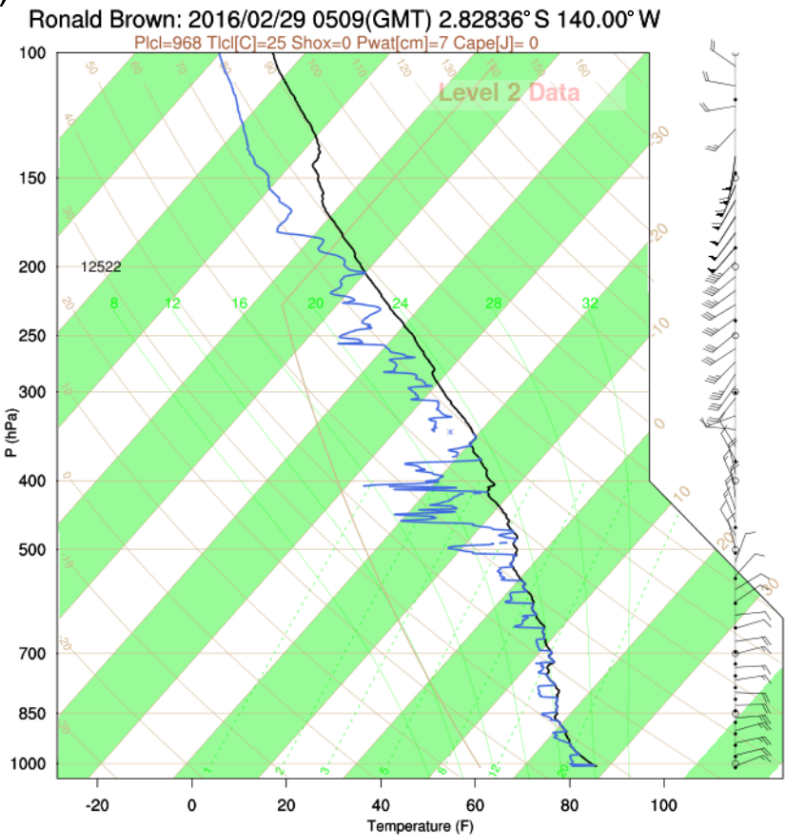

(b)

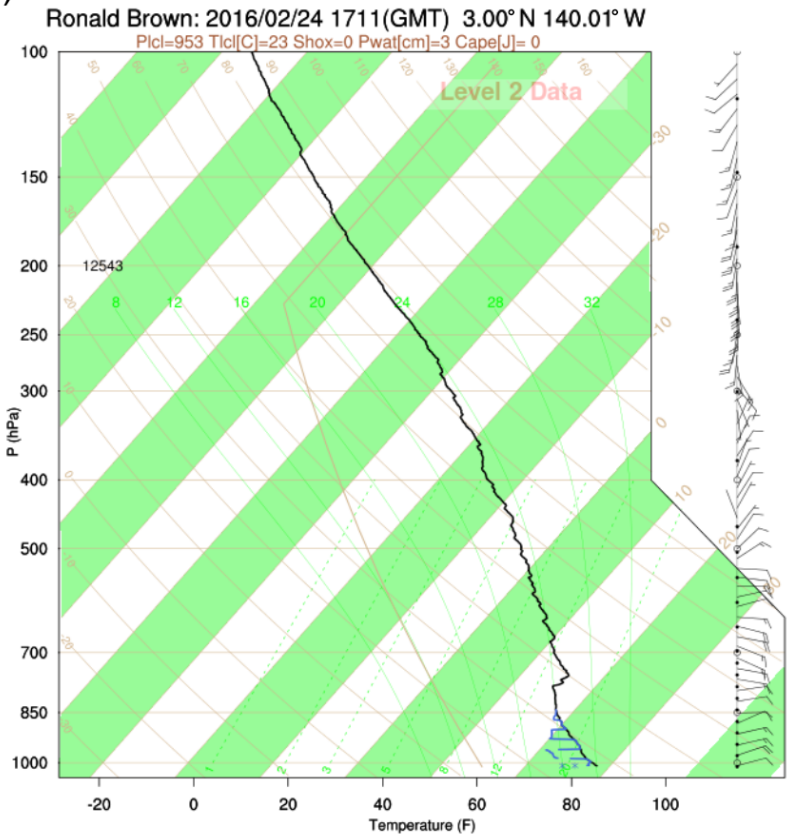

(d)

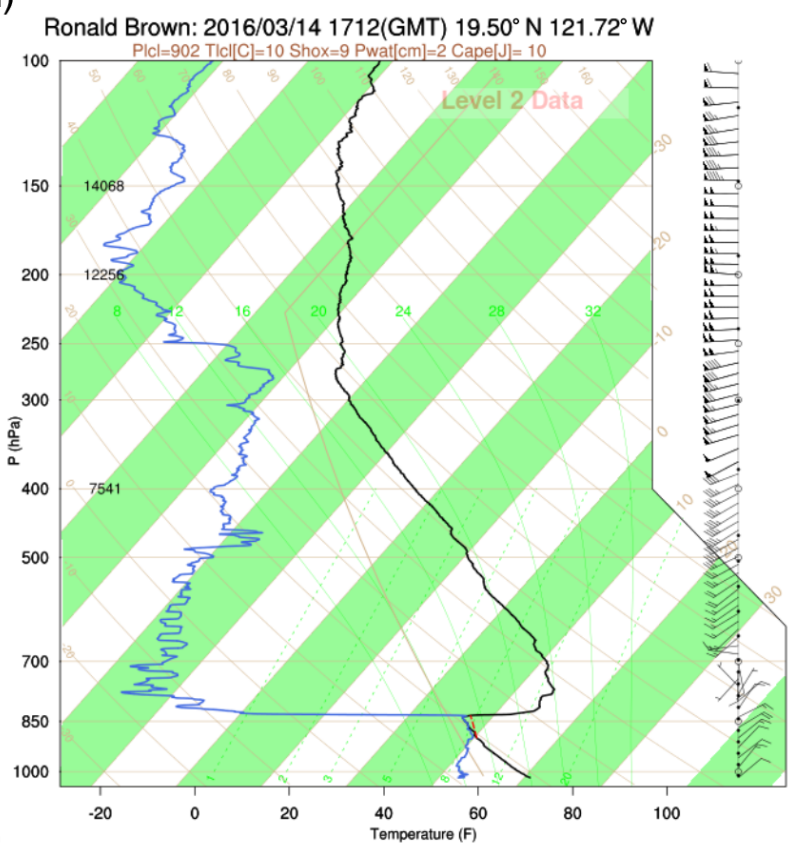

Figure 7. Examples of soundings with humidity issues that pass through ASPEN automated quality control.

rected for systematic errors (bias). Ciesielski et al. (2012) includes a discussion of random and systematic errors in modern thermodynamic soundings in that context, and contains citations to several relevant studies.

However, users need to be aware that automated quality control removes some but not all "bad" or "unrepresentative" data. For instance, RS92-SGP radiosondes con- tain two pulse-heated humidity sensors, both of which are reconditioned during the ground-check procedure (Vaisala Oyj, 2015). Data generally flow from them alternately. If the two sensors are for some reason giving realistic but different readings, large step-like swings in humidity are possible. These swings may be very obvious (Fig. 7a) or be followed by failure of both sensors (Fig. 7b). Sometimes the problem 


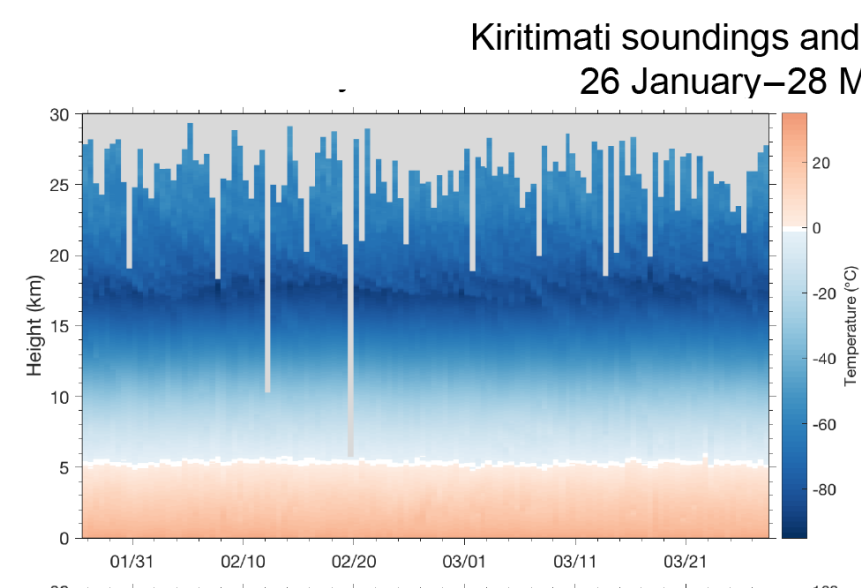

26 January-28 March 2016 UTC
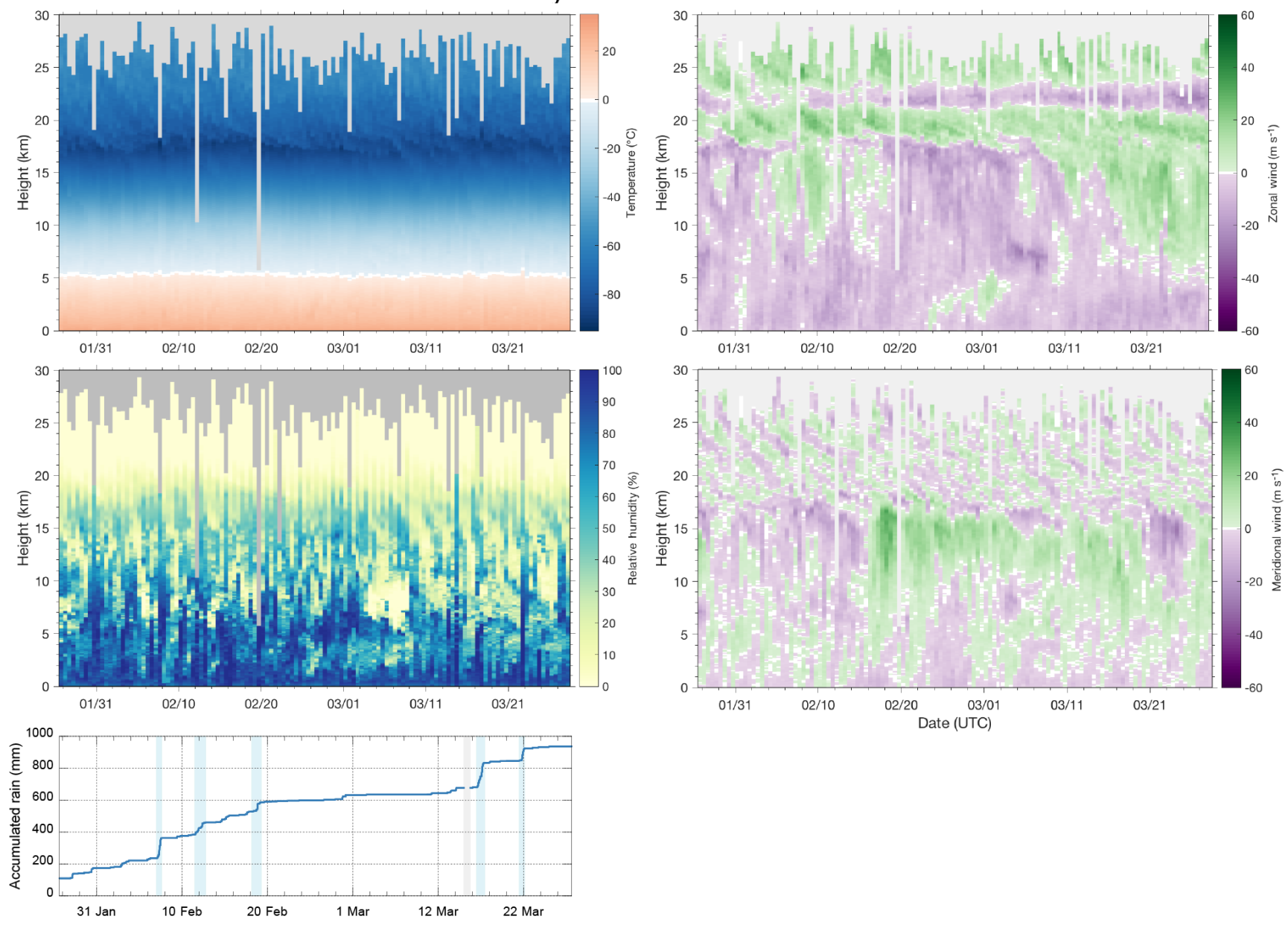

Figure 8. Vertical time-height sections of the temperature, relative humidity, and wind components measured by radiosondes launched from Kiritimati, together with the accumulated precipitation during the deployment (middle panel, shown only during the time range matching the time-height sections). Data from each sounding have been interpolated to a $25 \mathrm{~m}$ vertical grid before plotting and stretch along the $x$ axis to completely fill the time between launches, while grey shading indicates no available data. The time between the penultimate and final launches is duplicated in the plotting of that final launch. In the accumulated precipitation panel, light blue bars indicate the times of the major rain events that occurred during the sounding observation interval; the initial major rain event occurred before the first sounding was launched. Colors from www.ColorBrewer.org by Cynthia A. Brewer, Geography, Pennsylvania State University.

is clearly intermittent (Fig. 7d), and other times it is harder to discern whether it is intermittent or pervasive (Fig. 7c). While these swings may be obvious to the human eye and look non-meteorological, they do not trigger anything in ASPEN's automated quality control and are not removed. Situations like these would be systematically identified in the more time-consuming and person-intensive process of creating what Ciesielski et al. (2012) term "Level 3" and "Level 4" data sets.

\section{Characteristics of the data sets}

\subsection{Soundings from Kiritimati}

The 125 rawinsonde soundings from Kiritimati span nominal times 26 January 2016, 12:00 UTC to 28 March 2016, 00:00 UTC. The 27 February 2016, 00:00 UTC sounding launch was timed to be as coincident in time and space as possible with a dropsonde launched from the NOAA G-IV during one of its near-equatorial missions (Table 1). Height coverage of the CXENRR soundings was very good (Table 4, Fig. 8). Ninety-four percent of the soundings reached the Cold-Point Tropopause (CPT), defined here as the lowest temperature in the profile (Selkirk, 1993; Highwood and 
Table 4. Gross characteristics of the ENRR sounding data sets from Kiritimati and NOAA Ship Ronald H. Brown.

\begin{tabular}{lrr}
\hline & Kiritimati & $\begin{array}{r}\text { NOAA Ship } \\
\text { Ronald H. Brown }\end{array}$ \\
\hline Successful soundings & 125 & 193 \\
\hline Soundings reaching the tropopause & $117(94 \%)$ & $171(89 \%)$ \\
$40 \mathrm{hPa}$ & $110(88 \%)$ & $167(87 \%)$ \\
$30 \mathrm{hPa}$ & $103(82 \%)$ & $161(83 \%)$ \\
$25 \mathrm{hPa}$ & $86(69 \%)$ & $141(73 \%)$ \\
$25 \mathrm{~km}$ & $84(67 \%)$ & $139(72 \%)$ \\
\hline
\end{tabular}

Hoskins, 1998) that occurs above $15 \mathrm{~km}$ and with at least $2 \mathrm{~km}$ of sounding data above the level with the lowest temperature. The minimum height criteria were designed to prevent flagging of the top of a short sounding; because it is more than $1 \mathrm{~km}$ below the mean CPT heights found at Truk $\left(7.44^{\circ} \mathrm{N}, 151.83^{\circ} \mathrm{E}\right)$ by Mehta et al. (2011), we consider it unlikely that we are falsely identifying a Lower Tropopause (LT, Mehta et al., 2011) or other inversion below the CPT. Near-equatorial zonal winds at $40 \mathrm{hPa}$ are used to define the phase of the quasi-biennial oscillation (QBO, e.g., Baldwin et al., 2001), and $88 \%$ of the Kiritimati soundings reached that level. The Kiritimati soundings (Figs. 8, 9a) clearly show the complex layers of easterlies and westerlies observed in the Singapore soundings during early 2016 (cf. Fig. 2 in Newman et al., 2016) as well as downward propagating wave activity (reviewed in Baldwin et al., 2001).

For the observers on Kiritimati, the most notable atmospheric feature of our stay was the rainfall; our surface station recorded $0.938 \mathrm{~m}$ of rain, nearly as much as the longterm annual average observed at the Kiribati Meteorological Service's Kiritimati station. Most of that rain (69\%) came during six major events that were associated with the Intertropical Convergence Zone (ITCZ). The driest soundings (e.g., 7 March 2016 at 00:00 UTC, shown in Fig. 10) had only $0.04 \mathrm{~m}$ of precipitable water vapor and featured a deep very dry layer in the mid-troposphere with a temperature inversion at the base. This deep dry layer appears to be associated with the strong high-pressure system located between Hawaii and the California/Baja coast; in similar synoptic settings, the sharply bounded dry upper troposphere was also observed by dropsondes from the G-IV. At Kiritimati, profiles like this frequently contained incursions of marginally wetter air, such as seen in Fig. 10a just below $300 \mathrm{hPa}$ and between 400 and $500 \mathrm{hPa}$. The wettest soundings were collected when the ITCZ was over or very near the island (e.g., 22 March 2016 at 12:00 UTC, Fig. 11) and measured as much as $0.08 \mathrm{~m}$ of precipitable water vapor, with saturated or nearly saturated conditions extending up to the middle of the troposphere. In this instance, with the high centered near $35^{\circ} \mathrm{N}$, the ITCZ extended west of $160^{\circ} \mathrm{W}$ and was analyzed directly over Kiritimati at 12:00 UTC. From 10:10 to 17:59 UTC on
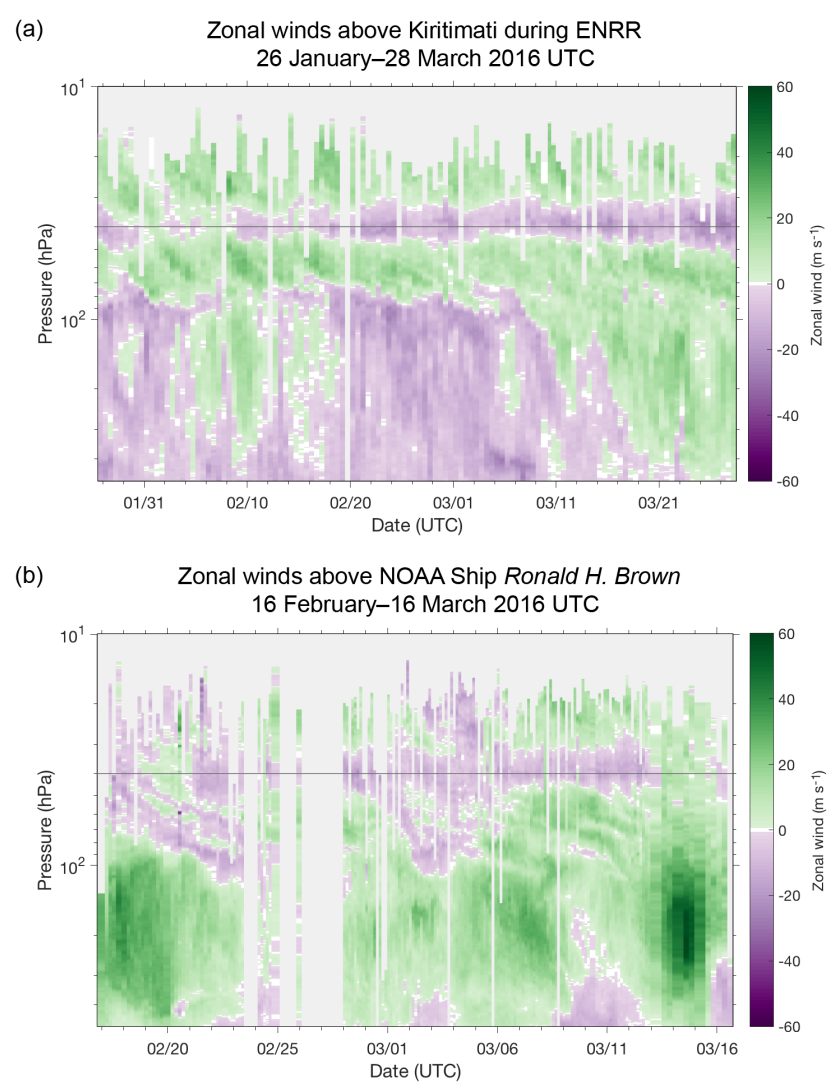

Figure 9. Zonal winds in the upper troposphere and lower stratosphere during ENRR, as measured by radiosondes launched from (a) Kiritimati and (b) NOAA Ship Ronald H. Brown. Colors from www.ColorBrewer.org by Cynthia A. Brewer, Geography, Pennsylvania State University.

22 March 2016, our station at Kiritimati recorded $75 \mathrm{~mm}$ of rainfall.

\subsection{Soundings from NOAA Ship Ronald H. Brown}

There are 193 rawinsonde observations from NOAA Ship Ronald H. Brown; the nominal time of the first was 16 February 2016, 19:00 UTC and, of the last, 16 March 2016, 12:00 UTC. Three were launched to coincide with nearby dropsondes from the G-IV (Table 1). Height coverage was also very good at this station (Table 4, Fig. 12), with $89 \%$ of the radiosondes reaching the CPT and $87 \%$ reaching $40 \mathrm{hPa}$. When viewed in a simple time-height section (Fig. 12), the ability to identify lower-stratospheric phenomena is complicated by the ship's movement into, through, and out of the near-equatorial zone. However, the stacked easterlies/westerlies/easterlies observed at Kiritimati (Fig. 9a) and at Singapore (Newman et al., 2016) are clearly present in early to mid-March 2016 (Fig. 9b), and fine-scale descending waves are evident in the lower stratosphere above about $20 \mathrm{~km}$ through much of the cruise (Fig. 12). The ship's 
(a)

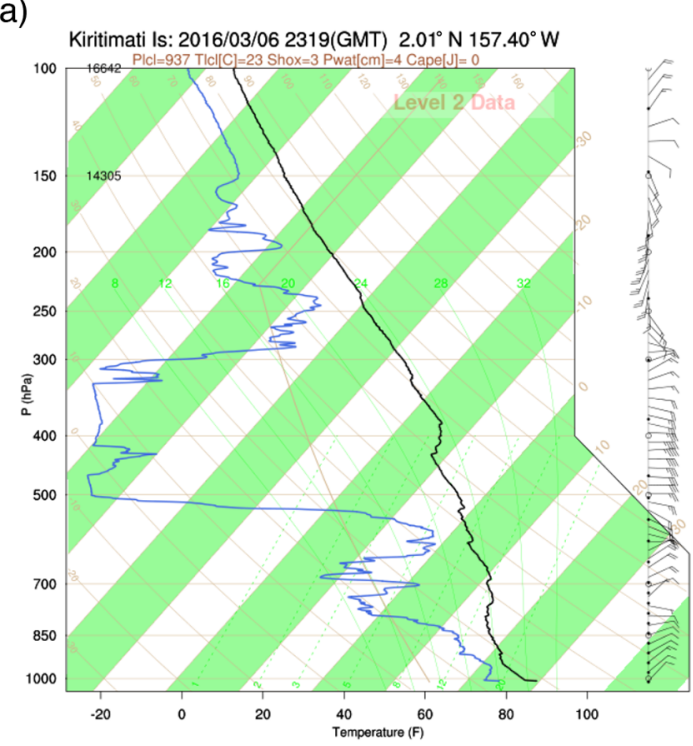

(b)

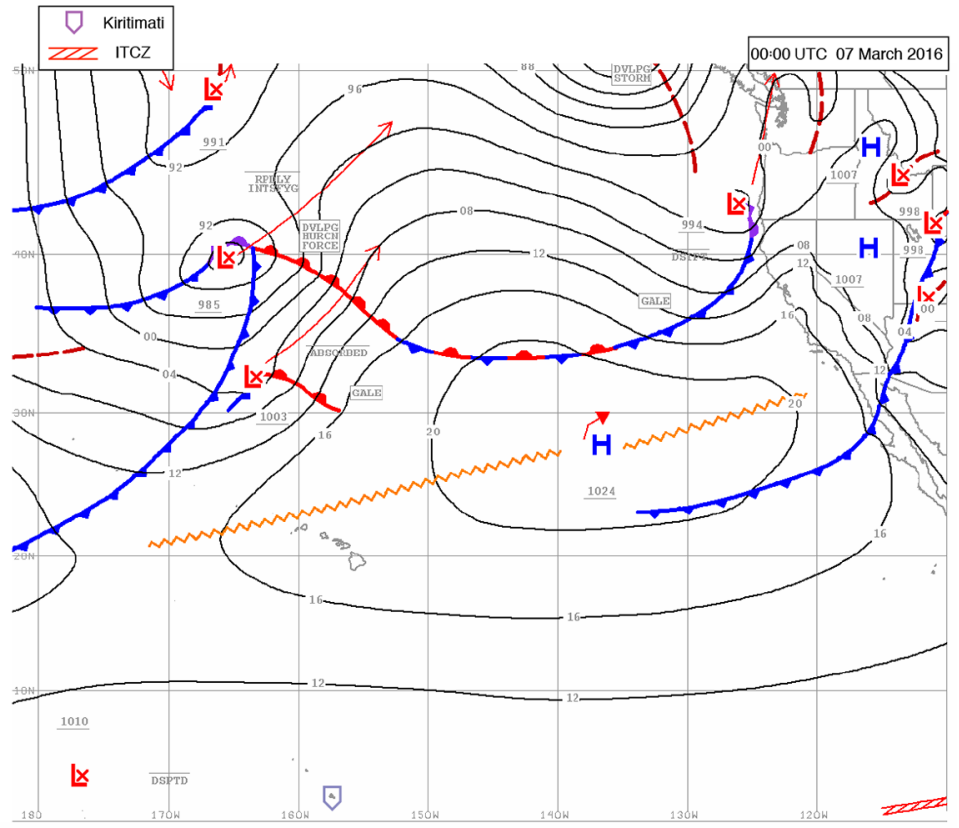

Figure 10. The 7 March 2016, 00:00 UTC sounding, which featured extremely dry air between 300 and $500 \mathrm{hPa}$, was the driest one collected at CXENRR. A coincident surface analysis shows a strong subtropical high-pressure system east-northeast of Hawaii and the Northern Hemisphere ITCZ confined to the furthest eastern regions of the Pacific, leaving Kiritimati $\left(2.0^{\circ} \mathrm{N}, 157.4^{\circ} \mathrm{W}\right)$ and the rest of the central equatorial Pacific in a broad zonal band of weak surface pressure gradients.

(a)

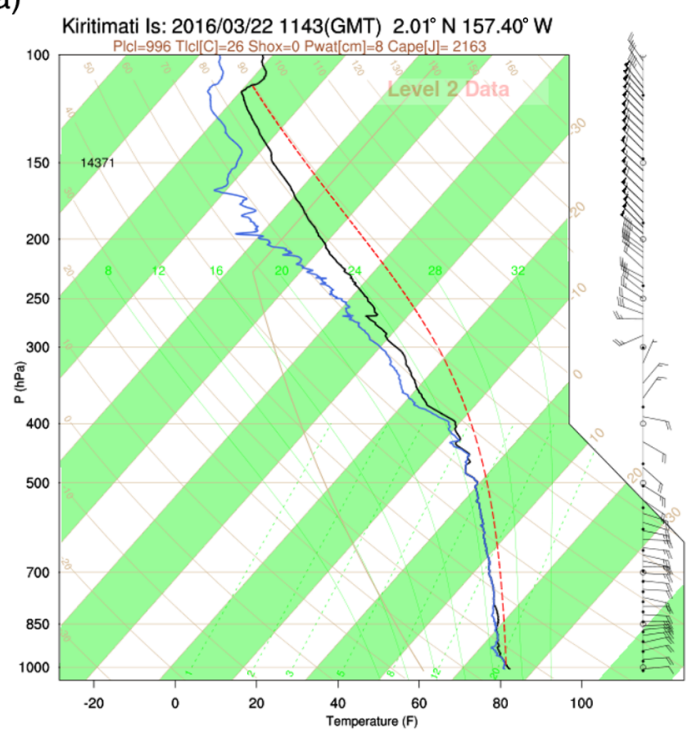

(b)

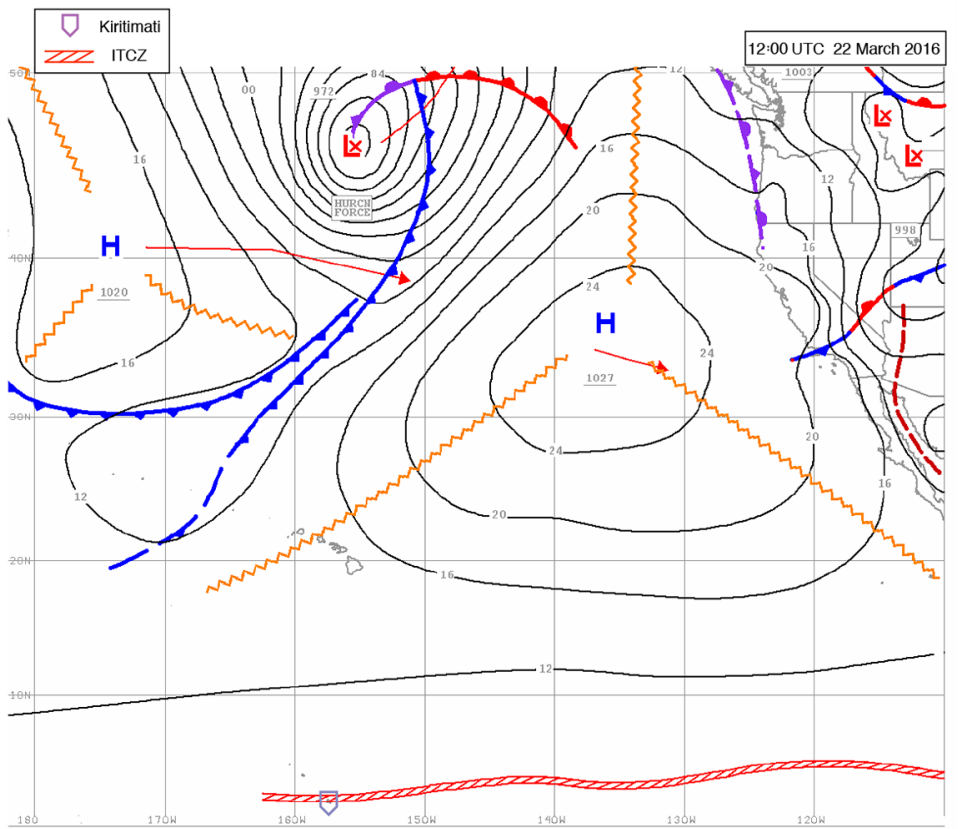

Figure 11. The 22 March 2016, 12:00 UTC sounding, the wettest one collected at CXENRR, was launched while the ITCZ was located over Kiritimati. 


\section{NOAA Ship Ronald $H$. Brown soundings and position during ENRR 16 February-16 March 2016 UTC}
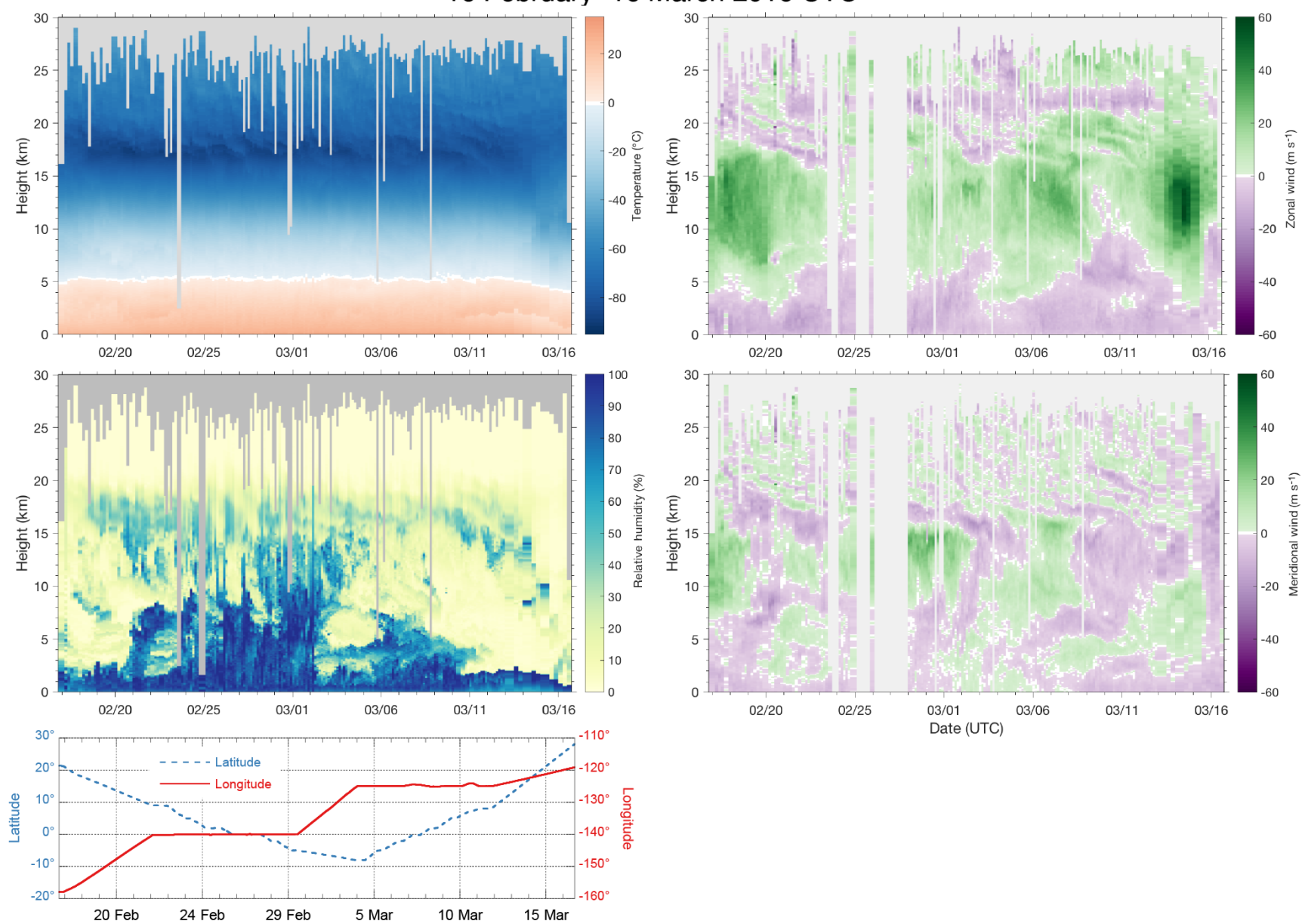

Figure 12. Vertical time-height sections of the temperature, relative humidity, and wind components measured by radiosondes launched from NOAA Ship Ronald H. Brown, together with the ship's position (middle panel). Data from each sounding have been interpolated to a $25 \mathrm{~m}$ vertical grid before plotting, and stretch along the $x$ axis to completely fill the time between launches. The time between the penultimate and final launches is duplicated in the plotting of that final launch. Grey shading indicates no available data. Colors from www.ColorBrewer.org by Cynthia A. Brewer, Geography, Pennsylvania State University.

soundings captured a wide variety of conditions, including extremely dry layers between 300 and $500 \mathrm{hPa}$ (Fig. 13a, collected when the ship was north of the ITCZ and on the edge of the Northern Hemisphere subtropical high) and strongly capped marine boundary layers (Fig. 13b) in the northern parts of the cruise, as well as deep tropical moisture nearer the Equator (Fig. 13c, d).

\section{Data availability and use}

The NOAA's National Center for Environmental Information (NCEI) is the archival location for these ENRR data sets. The DOIs are as follows: Level 2 rawinsonde data from Kiritimati (https://doi.org/10.7289/V55Q4T5K), and Level 2 rawinsonde data from NOAA Ship Ronald H. Brown
(https://doi.org/10.7289/V5X63K15). The data sets, together with sample code to read them and skew-T plots extending to $100 \mathrm{hPa}$, are also available from NOAA/ESRL/PSD at https://www.esrl.noaa.gov/psd/enso/rapid_response/data pub/. Users of these data must cite the appropriate DOI and reference the data as indicated below.

Cox, C., D. Wolfe, L. Hartten, and P. Johnston: El Niño Rapid Response (ENRR) Field Campaign: Radiosonde Data (Level 2) from the NOAA Ship Ronald H. Brown, February-March 2016 (NCEI Accession 0161527), Version 1.1, NOAA/National Centers for Environmental Information, https://doi.org/10.7289/V5X63K15, 2017.

Hartten, L., P. Johnston, C. Cox, and D. Wolfe: El Niño Rapid Response (ENRR) Field Campaign: Radiosonde Data (Level 2) from Kiritimati Island, January- 
(a)

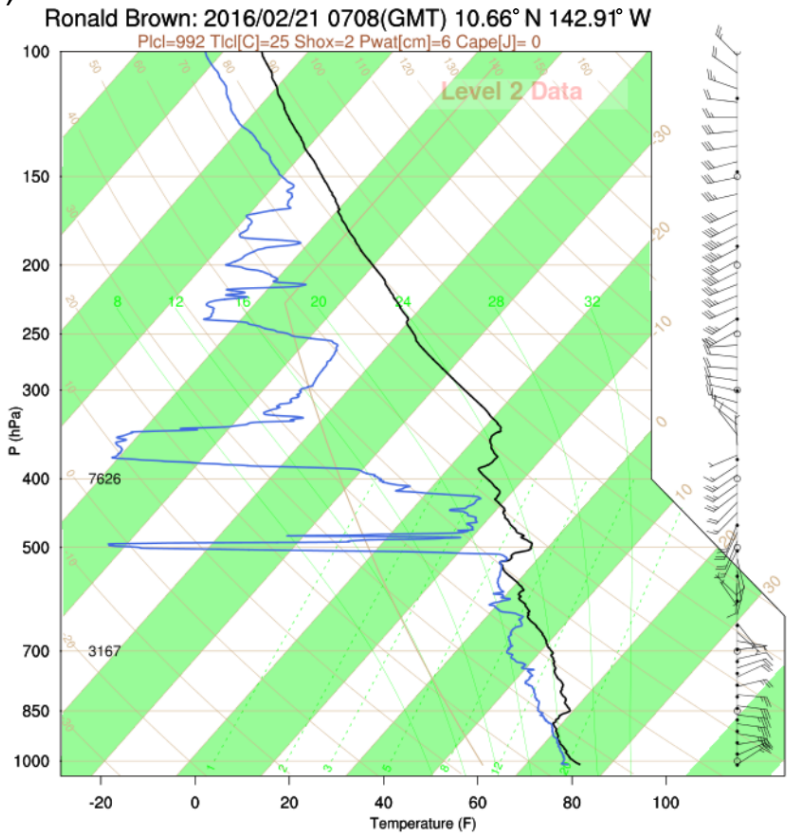

(c)

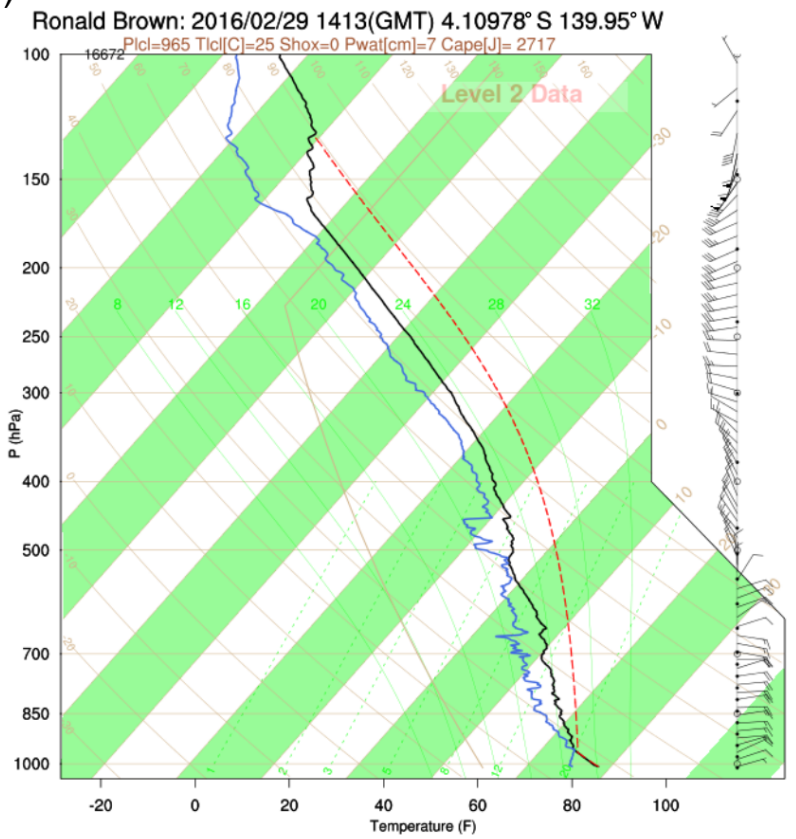

(b)

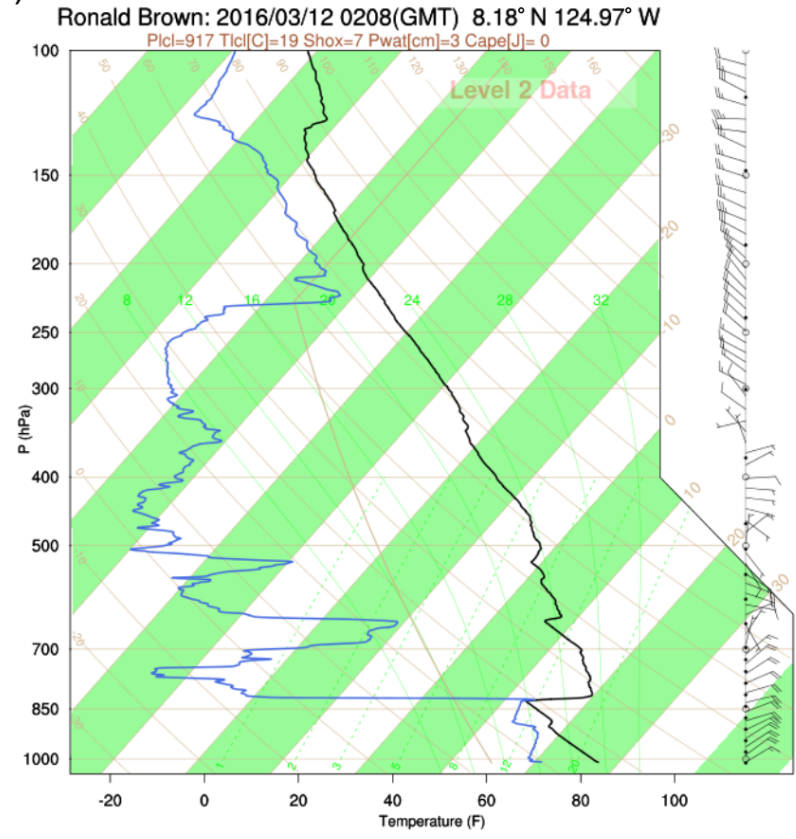

(d)

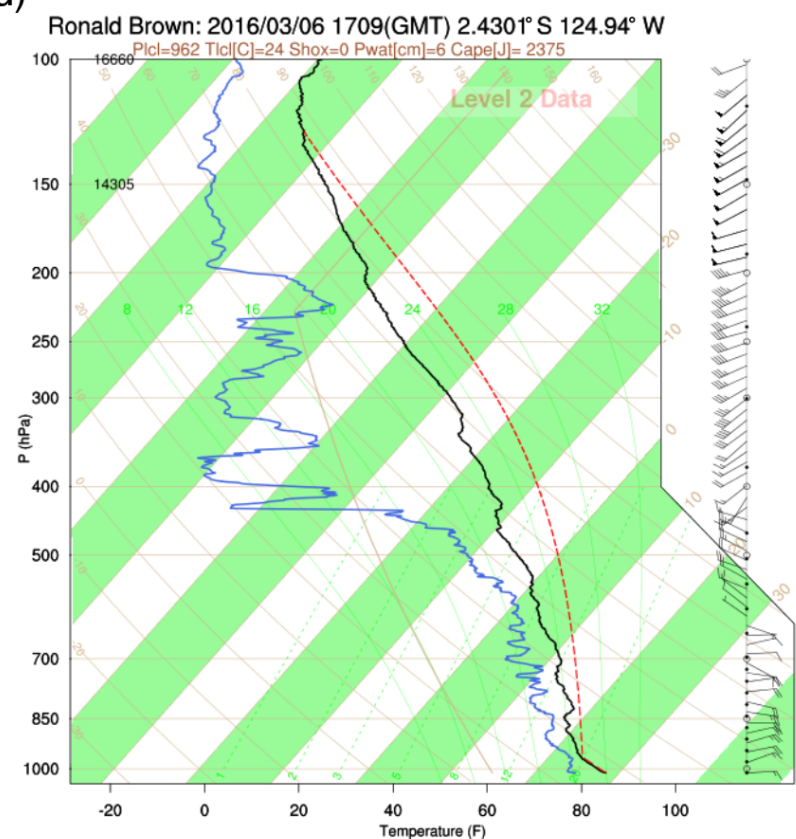

Figure 13. Examples of tropospheric conditions captured by soundings taken from NOAA Ship Ronald H. Brown during ENRR.

March 2016 (NCEI Accession 0161525), Version 1.1, NOAA /National Centers for Environmental Information, https://doi.org/10.7289/V55Q4T5K, 2017.

Each data set is comprised of many separate files, one for each sounding. The files are in the NASA Ames Format for Data Exchange ("NASA-Ames Format") which is written in plain (ascii) text, making it highly portable to differ- ent computers and easily accessible to users who have limited computer resources. Detailed explanations of the format are found in Gaines and Hipskind (1998) and at the Centre for Environmental Data Analysis (CEDA) website (Centre for Environmental Data Analysis, 2002). NASA-Ames Format requires certain metadata in various header sections and provides for additional optional headers; we have endeav- 
ored to take advantage of this aspect to make each file selfdescribing. It also requires that the total number of header lines be the first number in the first line of the file, and that the data following the header lines be space-delimited. Our files use the last header line to provide rudimentary column headers for the data that follow, to make it easier to import the data into spreadsheets or to quickly examine them by eye. Time is the independent variable in each file and is given in seconds since launch time. Users working with the data from Kiritimati, especially those interacting with residents and local meteorological data collections, may want to be aware that in terms of civil time Kiritimati is in the Line Island Time (LINT) time zone $(\mathrm{UTC}+14)$.

\section{Conclusions}

The ENRR Field Campaign, conducted in January-March 2016 during a very strong El Niño event, included a wide variety of special intensive observations. Among those were frequent radiosonde launches from Kiritimati $\left(2.0^{\circ} \mathrm{N}\right.$, $157.4^{\circ} \mathrm{E}$ ) and from NOAA Ship Ronald H. Brown during its cruise along the near-equatorial TAO buoy transects at 140 and $125^{\circ} \mathrm{W}$. One radiosonde from Kiritimati and three from the ship were launched in coordination with dropsonde releases from the NOAA Gulfstream-IV (G-IV; see Table 1), which conducted numerous research flights over the tropical Pacific as part of the ENRR field campaign (Dole et al., 2018). This resulted in four pairs of radiosonde and dropsonde soundings, each pair separated in (horizontal) launch location by only $28-54 \mathrm{~km}$ and launched within a $5-8 \mathrm{~min}$ window.

We have reprocessed 125 soundings from Kiritimati and 193 from the ship, using corrected surface pressure for the radiosonde calibration and corrected surface meteorology as the first point of the sounding. We then subjected them to automated quality control via NCAR's ASPEN software. ASPEN removed and flagged values that failed objective checks; smoothed the wind, pressure, temperature, and relative humidity profiles; recomputed geopotential height; and computed the radiosonde ascent rate. We have written the resulting data to NASA-Ames format (ASCII) files, incorporating rich metadata into the header together with mandated information. The results are what Ciesielski et al. (2012) define as "Stage 2" or "Level 2" sounding data sets: data in a uniform, digital, easily read format which have been processed with automated quality-control checks to remove bad values. While both sites also collected the data reported by the radiosondes as they fell after balloon burst, only the data collected during radiosonde ascent have been reprocessed and included in these data sets.

The Kiritimati data set consists of 9.5 weeks of twicedaily soundings in the midst of this El Niño episode's warm central-Pacific waters. Since $82 \%$ of the soundings reached at least $30 \mathrm{hPa}$, these data show a portion of the unusual
2015-2016 QBO as well as the incursions of the ITCZ which led to nearly a meter of rainfall during our deployment. Data from the 4-week cruise of NOAA Ship Ronald H. Brown include eight soundings per day during the 19 days spent at $8^{\circ} \mathrm{N}-8^{\circ} \mathrm{S}$ between 140 and $125^{\circ} \mathrm{W}$. Height coverage was comparable to that at Kiritimati, with $83 \%$ reaching $30 \mathrm{hPa}$. The ship soundings captured lower-stratospheric features of the QBO and also sampled a variety of tropical marine tropospheric settings. The data from both sites should be useful for a variety of research studies and reanalyses of the structure and impact of the strong 2015/16 El Niño event.

Author contributions. All authors spent at least 2 weeks at Kiritimati or 4 weeks aboard the ship launching radiosondes. CJC, PEJ, and DEW reprocessed soundings from Kiritimati and NOAA Ship Ronald H. Brown in consultation with LMH; PEJ applied ASPEN to the reprocessed soundings. LMH assembled metadata and created the file headers with input from all co-authors, and then created the final files. LMH prepared the manuscript with input from all co-authors.

Competing interests. The authors declare that they have no conflict of interest.

Acknowledgements. The ENRR Field Campaign was funded by the NOAA through the Office of Oceanic and Atmospheric Research (OAR) as well as the National Weather Service (NWS), the Office of Marine and Aviation Operations (OMAO) and the National Environmental Satellite, Data and Information Service (NESDIS). We thank the Republic of Kiribati for allowing NOAA to conduct research on Kiritimati, and the Kiribati Meteorological Service for engaging with our observers. The crew of NOAA Ship Ronald H. Brown, in particular Captain Robert Kamphaus, NOAA/OMAO Survey Technicians Joshua Gunter and Mark Bradley, and NOAA/OMAO Lieutenant Adrienne Hopper, were very supportive of our staff and operations. On Kiritimati, the management and staff of the Captain Cook Hotel welcomed ENRR into their lives (helium canisters and all) and made our work and stay very pleasant, while John Bryden's logistical support and supplies were critical to our observational success. We extend our thanks to Paul Ciesielski (Colorado State University) for pre- and post-deployment conversations about quality assurance and quality control; to Tina Schiffbauer and William Otto (PSD) for ensuring both crews had balloons and helium; to Timothy Coleman (CIRES and PSD) and Daniel Gottas (PSD) for their work on making real-time file transfer a reality; to Cathy Smith (CIRES and PSD) for plotting our soundings in real time and later helping shepherd the data through the archival process; and to Don Hooper (CIRES and PSD) for the scripts which transformed the post-processed data into final form and which enable users to browse skew-T plots of them on a web page. We appreciate Gary Wick's (PSD) and Ola Persson's (CIRES and PSD) careful reading of and though-provoking comments about the manuscript. VGF files for the surface analyses were provided by Raymond Tanabe of NOAA/NWS Pacific Region Headquarters and very kindly turned 
into maps by David Plummer of NOAA/National Centers for Environmental Prediction (NCEP) Central Operations.

Edited by: David Carlson

Reviewed by: two anonymous referees

\section{References}

Baldwin, M. P., Gray, L. J., Dunkerton, T. J., Hamilton, K., Haynes, P. H., Randel, W. J., Holton, J. R., Alexander, M. J., Hirota, I., Horinouchi, T., Jones, D. B. A., Kinnersley, J. S., Marquardt, C., Sato, K., and Takahashi, M.: The quasi-biennial oscillation, Rev. Geophys., 39, 179-229, https://doi.org/10.1029/1999RG000073, 2001.

Bourlès, B., Lumpkin, R., McPhaden, M. J., Hernandez, F., Nobre, P., Campos, E., Yu, L., Planton, S., Busalacchi, A., Moura, A. D., Servain, J., and Trotte, J.: THE PIRATA PROGRAM, B. Am. Meteorol. Soc., 89, 1111-1126, 10.1175/2008bams2462.1, 2008. Centre for Environmental Data Analysis (CEDA): NASA Ames Format for Data Exchange, available at: http://cedadocs.ceda.ac. uk/73/4/index.html (last access: 18 January 2018), 2002.

Ciesielski, P. E., Haertel, P. T., Johnson, R. H., Wang, J., and Loehrer, S. M.: Developing High-Quality Field Program Sounding Data sets, B. Am. Meteorol. Soc., 93, 325-336, https://doi.org/10.1175/BAMS-D-11-00091.1, 2012.

Climate Prediction Center (CPC) and International Research Institute for Climate and Society (IRI): El Niño/Southern Oscillation (ENSO) Diagnostic Discussion, June 2015, available at: http://www.cpc.ncep.noaa.gov/products/analysis_monitoring/ enso_disc_jun2015/ensodisc.html (last access: 2 March 2017), 2015a.

Climate Prediction Center (CPC) and International Research Institute for Climate and Society (IRI): El Niño/Southern Oscillation (ENSO) Diagnostic Discussion, August 2015, available at: http://www.cpc.ncep.noaa.gov/products/analysis_ monitoring/enso_disc_aug2015/ensodisc.html (last access: 2 March 2017), 2015b.

Cox, C., Wolfe, D., Hartten, L., and Johnston, P.: El Niño Rapid Response (ENRR) Field Campaign: Radiosonde Data (Level 2) from the NOAA Ship Ronald H. Brown, February-March 2016 (NCEI Accession 0161527), Version 1.1, NOAA /National Centers for Environmental Information, https://doi.org/10.7289/V5X63K15, 2017a.

Cox, C., Wolfe, D., Hartten, L., and Johnston, P.: El Niño Rapid Response (ENRR) Field Campaign: Surface Meteorological and Ship Data from the NOAA Ship Ronald H. Brown, February-March 2016 (NCEI Accession 0161528), Version 1.1, NOAA /National Centers for Environmental Information, https://doi.org/10.7289/V5SF2T80, 2017b.

de Szoeke, S. P., Fairall, C. W., Wolfe, D. E., Bariteau, L., and Zuidema, P.: Surface Flux Observations on the Southeastern Tropical Pacific Ocean and Attribution of SST Errors in Coupled Ocean-Atmosphere Models, J. Climate, 23, 4152-4174, https://doi.org/10.1175/2010jcli3411.1, 2010.

Dole, R. M., Spackman, J. R., Newman, M., Compo, G. P., Smith, C. A., Hartten, L. M., Barsugli, J. J., Webb, R. S., Hoerling, M. P., Cifelli, R., Wolter, K., Barnet, C. D., Gehne, M., Gelaro, R., Kiladis, G. N., Abbott, S., Akish, E., Albers, J., Brown, J. M.,
Cox, C. J., Darby, L., Boer, G. d., DeLuisi, B., Dias, J., Dunion, J., Eischeid, J., Fairall, C., Gambacorta, A., Gorton, B. K., Hoell, A., Intrieri, J., Jackson, D., Johnston, P. E., Lataitis, R., Mahoney, K. M., McCaffrey, K., McColl, H. A., Mueller, M. J., Murray, D., Neiman, P. J., Otto, W., Persson, O., Quan, X.-W., Rangwala, I., Ray, A. J., Reynolds, D., Dellaripa, E. R., Rosenlof, K., Sakaeda, N., Sardeshmukh, P. D., Slivinski, L. C., Smith, L., Solomon, A., Swales, D., Tulich, S., White, A., Wick, G., Winterkorn, M. G., Wolfe, D. E., and Zamora, R.: Advancing Science and Services during the 2015/16 El Niño: The NOAA El Niño Rapid Response Field Campaign, B. Am. Meteorol. Soc., 99, 975-1001, https://doi.org/10.1175/bams-d-16-0219.1, 2018.

Gaines, S. E. and Hipskind, R. S.: Format Specification for Data Exchange, Version 1.3, NASA Ames Research Center, 30, available at: http://cloud1.arc.nasa.gov/solve/archiv/archive.tutorial. html, 1998.

Hartten, L., Johnston, P., Cox, C., and Wolfe, D.: El Niño Rapid Response (ENRR) Field Campaign: Radiosonde Data (Level 2) from Kiritimati Island, January-March 2016 (NCEI Accession 0161525), Version 1.1, NOAA /National Centers for Environmental Information, https://doi.org/10.7289/V55Q4T5K, 2017a.

Hartten, L., Johnston, P., Cox, C., and Wolfe, D.: El Niño Rapid Response (ENRR) Field Campaign: Surface Meteorological Data from Kiritimati Island, January-March 2016 (NCEI Accession 0161526), Version 1.1, NOAA /National Centers for Environmental Information, https://doi.org/10.7289/V51Z42H4, 2017b.

Hartten, L. M., Cox, C. J., Johnston, P. E., Wolfe, D. E., Abbott, S., and McColl, H. A.: Central-Pacific surface meteorology from the 2016 El Niño Rapid Response (ENRR) field campaign, Earth Syst. Sci. Data, 10, 1139-1164, https://doi.org/10.5194/essd-101139-2018, 2018.

Highwood, E. J. and Hoskins, B. J.: The tropical tropopause, Q. J. Roy. Meteor. Soc., 124, 1579-1604, https://doi.org/10.1002/qj.49712454911, 1998.

Lebel, T., Parker, D. J., Flamant, C., Bourlès, B., Marticorena, B., Mougin, E., Peugeot, C., Diedhiou, A., Haywood, J. M., Ngamini, J. B., Polcher, J., Redelsperger, J. L., and Thorncroft, C. D.: The AMMA field campaigns: multiscale and multidisciplinary observations in the West African region, Q. J. Roy. Meteor. Soc., 136, 8-33, https://doi.org/10.1002/qj.486, 2010.

Martin, C.: ASPEN (Atmospheric Sounding Processing ENvironment) User Manual, National Center for Atmospheric Research, Boulder, Colorado, 56, available at: https://www.eol.ucar.edu/ content/aspen (last access: 17 August 2016), 2007.

Mehta, S. K., Venkat Ratnam, M., and Krishna Murthy, B. V.: Characteristics of the tropical tropopause over different longitudes, J. Atmos. Sol.-Terr. Phy., 73, 2462-2473, https://doi.org/10.1016/j.jastp.2011.09.006, 2011.

Morate, O.: 2015 Population and Housing Census Volume 1: Management Report and Basic Tables, National Statistics Office, Ministry of Finance, Bairiki, Tarawa, Republic of Kiribati, 197, available at: http://www.mfed.gov.ki/publications/ census-report-2015-volume-i-final-report (last access: 11 January 2017), 2016.

Nalli, N. R., Joseph, E., Morris, V. R., Barnet, C. D., Wolf, W. W., Wolfe, D., Minnett, P. J., Szczodrak, M., Izaguirre, M. A., Lumpkin, R., Xie, H., Smirnov, A., King, T. S., and Wei, J.: Multiyear Observations of the Tropical Atlantic Atmosphere: Multidisciplinary Applications of the NOAA Aerosols and Ocean 
Science Expeditions, B. Am. Meteorol. Soc., 92, 765-789, https://doi.org/10.1175/2011bams2997.1, 2011.

Newman, P. A., Coy, L., Pawson, S., and Lait, L. R.: The anomalous change in the QBO in 2015-2016, Geophys. Res. Lett., 43, 8791-8797, https://doi.org/10.1002/2016GL070373, 2016.

Office of the Federal Coordinator for Meteorology (OFCM): Federal Meteorological Handbook No. 3: Rawinsonde And Pibal Observations, U.S. Dept. of Commerce, National Oceanic and Atmospheric Administration, Washington, DC, FCM-H31997, 191, available at: http://www.ofcm.gov/publications/fmh/ allfmh2.htm (last access: 22 December 2015), 2006.

Scott, D. A. (Ed.): A Directory of Wetlands in Oceania, Slimbridge, UK and Kuala Lumpur, Malaysia, 370 pp., 1993.

Selkirk, H. B.: The tropopause cold trap in the Australian monsoon during STEP/AMEX 1987, J. Geophys. Res.-Atmos., 98, 85918610, https://doi.org/10.1029/92JD02932, 1993.

Servain, J., Busalacchi, A. J., McPhaden, M. J., Moura, A. D., Reverdin, G., Vianna, M., and Zebiak, S. E.: A Pilot Research Moored Array in the Tropical Atlantic (PIRATA), B. Am. Meteorol. Soc., 79, 2019-2032, https://doi.org/10.1175/15200477(1998)079<2019:Aprmai>2.0.Co;2, 1998.
University Corporation for Atmospheric Research: Atmospheric Sounding Processing ENvironment (ASPEN), available at: https: //www.eol.ucar.edu/content/aspen, last accessed 21 June 2016.

Vaisala Oyj: User's Guide: Ground Check Set GC25, Vaisala Oyj, M210329EN-E, Helsinki, Finland, 43 pp., 2006.

Vaisala Oyj: DigiCORA ${ }^{\circledR}$ Technical Reference, M210489EN-J, Vaisala Oyj, Helsinki, Finland, 86 pp., 2010a.

Vaisala Oyj: DigiCORA ${ }^{\circledR}$ User's Guide, M210488EN-F, Vaisala Oyj, Helsinki, Finland, 113 pp., 2010b.

Vaisala Oyj: Vaisala Radiosonde RS92-SGP User's Guide, Vaisala Oyj, M210295EN-J, Helsinki, Finland, 54 pp., 2015.

World Meteorological Organization: Manual on the Global Observing System, 2010 edn., WMO (Series) no. 544, Secretariat of the World Meteorological Organization, Geneva, Switzerland, 2013. 